\title{
Assessing the Economic Vulnerability of Small Island Developing States and the Least Developed Countries
}

\author{
Patrick Guillaumont
}

June 2007

\begin{abstract}
Macro vulnerability of the small island developing states (SIDS) as well as of least developed countries (LDCs) has been an increasing concern for the international community. This concern has led to the creation of the economic vulnerability index (EVI) in order to assess comparatively the degree of structural economic vulnerability of countries. Structural vulnerability results mainly from natural or external shocks faced by countries, and their exposure to these shocks. General vulnerability, on the other hand, depends on the resilience of the country which is determined mainly by policy.
\end{abstract}

We first explain how vulnerability affects growth and development, particularly in small developing countries, by considering the consequences of the size of shocks, the exposure to shocks and the consequences of resilience. The channels of transmission are also explored in an attempt to explain how instability slows down poverty reduction not only directly but also through lower growth. We also examine how the EVI, as a synthetic measure of structural vulnerability, has been designed and how it can be used to compare

Keywords: vulnerability, instability, shocks, growth handicaps, least developed countries, small island developing states, aid allocation

JEL classification: F35, N10, I39

Copyright (C) UNU-WIDER 2007

* CERDI, CNRS and Université d’Auvergne, email: p.guillaumont@cerdi.u-clermont1.fr

This study has been prepared within the UNU-WIDER project on Fragility and Development, directed by Mark McGillivray and Amelia Santos-Paulino.

UNU-WIDER gratefully acknowledges the financial contributions to the project by the Australian Agency for International Development (AusAID), the Finnish Ministry for Foreign Affairs, and the UK Department for International Development-DFID.

UNU-WIDER also acknowledges the financial contributions to the research programme by the governments of Denmark (Royal Ministry of Foreign Affairs), Norway (Royal Ministry of Foreign Affairs), and Sweden (Swedish International Development Cooperation Agency—Sida). 
SIDS and LDCs. Both groups are more vulnerable than other developing countries, but in a different way.

Lastly, the paper considers some of complementary implications on policy of the availability of the EVI with regard to the LDCs and the SIDS. It argues that EVI is a relevant tool not only for the identification of LDCs, but also for geographical allocation of aid allocation so as to favour vulnerable countries, including both LDCs and SIDS, even though not all SIDS qualify as LDCs. In both exercises, however, the EVI cannot be the only criterion.

\section{Acronyms}

CDP Committee for Development Planning (of the UN; later renamed the Committee for Development Policy)

EVI economic vulnerability index

LDCs least developed countries

REER real effective exchange rate

SIDS small island developing states

The World Institute for Development Economics Research (WIDER) was established by the United Nations University (UNU) as its first research and training centre and started work in Helsinki, Finland in 1985. The Institute undertakes applied research and policy analysis on structural changes affecting the developing and transitional economies, provides a forum for the advocacy of policies leading to robust, equitable and environmentally sustainable growth, and promotes capacity strengthening and training in the field of economic and social policy making. Work is carried out by staff researchers and visiting scholars in Helsinki and through networks of collaborating scholars and institutions around the world.

www.wider.unu.edu

publications@wider.unu.edu

UNU World Institute for Development Economics Research (UNU-WIDER)

Katajanokanlaituri 6 B, 00160 Helsinki, Finland

Typescript prepared by Liisa Roponen at UNU-WIDER

The views expressed in this publication are those of the author(s). Publication does not imply endorsement by the Institute or the United Nations University, nor by the programme/project sponsors, of any of the views expressed. 
Several reasons account for the fact that during the last decade a renewed interest has been focussed on macroeconomic vulnerability and its related issues in the developing countries. This interest may have been triggered by highly visible events such as the sociopolitical problems that have disrupted economic growth in a number of African countries or the financial crises in Asian and other emerging countries. The renewed interest may also reflect international concern about the structural characteristics of specific groups of countries, as has been expressed in various UN meetings and resolutions. Two groups of countries thus have been considered with respect to vulnerability. The first, and the only official group, is the category of the least developed countries (LDCs), established by the UN General Assembly in 1971. The second-a large and more informal group-is the small island developing states (SIDS). The need to assess the vulnerability of both country groups through an appropriate indicator has been highlighted.

First, SIDS have repeatedly expressed concern over their level of vulnerability, as evidenced at the 1994 Barbados Conference on Sustainable Development of Small Island Developing States. Following this conference which recommended 'the development of vulnerability indices and other indicators that reflect the status of small island developing countries and integrate ecological fragility and economic vulnerability', the UN General Assembly requested the Secretary General in 1996 to prepare a report on the vulnerability index and the Committee for Development Planning (CDP) to examine this index. In 1998, the UN Commission on Sustainable Development urged the CDP to present its findings and for other UN bodies to accord priority to the work on the vulnerability of SIDS. In 1999, after considering several available indicators, the Committee for Development Policy (the CDP renamed) proposed a new and relatively simple index (UN 1999) which was elaborated further at the following CDP sessions. Ten years after the Barbados Conference, the Mauritius Conference (December 2004) reiterated the concern of the international community about the vulnerability of small islands. Few days later, the tsunami confirmed the relevance of this concern.

Second, in accordance with CDP's own suggestion, the General Assembly requested the committee to consider 'the usefulness of the vulnerability index as a criterion for the designation of the least developed countries'. Since the category was established, the LDCs have been considered as low-income countries suffering from structural handicaps to growth. Initially, in addition to the level of income per capita, the criteria used to capture structural shortcomings were the literacy rate and the share of manufacturing in GDP. These were replaced in 1991 by two composite indices, one referring to human status, the other to economic diversification. In 1999, as noted above, the CDP proposed that in addition to the level of GDP per capita and an index of human capital, the new economic vulnerability index (EVI) should replace the diversification index as one of the criteria for identifying LDCs. In 2000 at its triennial review of the LDCs list, CDP implemented the EVI index as an identification criterion, utilizing it again in 2003 and 2006 with some revisions. This new vulnerability criterion, initial and revised versions, has been acknowledged by ECOSOC (E/2000/L.29 and E/2005/L.52). 
SIDS and LDCs constitute two very different, although overlapping, country groups. Among the 50 LDCs, twelve (24 per cent) are SIDS; two of which (and possibly a third) are about to exit the list. 1 These twelve countries represent more than 35 per cent of the 37 independent SIDS (there are 52 SIDS when dependent colonies are included). Most of the SID countries (85 per cent) do not qualify as low-income; some, in fact, have very high income. Among the LDCs, the majority or 58 per cent (39 countries) are fairly small countries (with population sizes smaller than those of the larger SIDS; Cuba has a population of 11 million). This also means that 45 per cent [(39-12)/(50-12)] of the LDCs not classified as SIDS are small countries. In brief, the two categories refer to countries that differ significantly in other characteristics but which face, to a large extent, problems associated with small size, in particular high economic vulnerability.

The economic vulnerability of a country can be defined by the risk of a (poor) country seeing its development hampered by the natural or external shocks it faces. Here we consider two main kinds of exogenous shocks as well as two main sources of vulnerability: (i) environmental or 'natural' shocks, such as earthquakes or volcanic eruptions, and the more frequent climatic shocks, such as typhoons and hurricanes, droughts, floods, etc., and (ii) external (trade- and exchange-related) shocks, such as slumps in external demand, world commodity prices instability (and correlated instability of terms of trade), international fluctuations of interest rates, etc. Other domestic shocks may also be generated by political instability or, more generally, by unforeseen political changes. These shocks, however, are not considered here, as far as they seem less 'exogenous'.

Vulnerability can be seen as the result of three components:

i) the size and frequency of the exogenous shocks, either observed (ex post vulnerability) or anticipated (ex ante vulnerability);

ii) exposure to shocks;

iii) the capacity to react to shocks, or resilience. ${ }^{2}$ Resilience depends more on current policy, is more easily reversed, and is less structural. But there may also be a structural element in the resilience component of vulnerability. 3

1 According to the decision of the UN General Assembly, Cape Verde and the Maldives are to be graduated from the list, respectively on 1 January 2008 and 1 January 2011. The graduation of Samoa has been recommended by the CDP in 2006, but has not yet been endorsed.

2 The concept of resilience is largely used in certain works more specifically oriented towards the environmental or natural sources of vulnerability (cf. Kaly et al. 1999). A distinction close to environmental vulnerability is given in Rodrik (1999) who, in looking at the risk of social conflict in countries facing external shocks, separately considers the severity of the shocks, the depth of latent social conflict (likely to increase the impact of the shocks), and the quality of conflict management institutions.

3 Consider, for instance, a small country that is a primary commodity exporter. Its vulnerability to trade shocks results, first, from the world price fluctuations, reflected by the instability of its terms of trade; second, from the exposure to shocks expressed by the ratio of (commodities) export to GDP; and finally, from the capacity of the country to efficiently manage such shocks. The size of the shocks for a small price-taker country (its export price instability) is clearly an exogenous factor of instability. Resilience, or the capacity to manage instability, depends on the policy pursued. The country (its export price instability) is clearly an exogenous factor of instability. Resilience, or the capacity to 
Thus, a distinction can be made between structural vulnerability, which results from factors that are independent of a country's current political will, and the vulnerability deriving from policy, which results from recent choices. For instance, the vulnerability of the Asian countries in the mid-1990s, after the 1997 crisis, is very different from the vulnerability of small economies or that of small islands which export raw materials. It is less structural, more the result of policy, thus more transient. This feature is clearly evident when vulnerability is measured according the probability of a financial crisis that can be estimated mainly from financial and policy variables (see, for instance, Berg and Patillo 1999; Goldstein, Kaminski and Reinhart 2000). If an index is to be used in selecting certain countries for the allocation of long-term support by the international community, what needs to be measured is naturally the structural vulnerability, which essentially results from the size of the shocks that can arise and the exposure to them.

For the purpose of this paper, another distinction needs to be done between economic vulnerability and ecological fragility. The UN's initial concern over vulnerability included both economic vulnerability and ecological fragility, but it quickly became clear that the two notions should be analysed separately. For instance, losses in biodiversity reflect ecological fragility and are not necessarily major elements of economic vulnerability. The ad hoc expert group commissioned by the UN on vulnerability clearly recognized this difference (which was reaffirmed by the CDP), while also acknowledging that economic vulnerability could be induced by natural factors, i.e., by the environment ('the relative susceptibility of economies to damage caused by natural disasters' UN 1999). Thus, environmentally-induced economic vulnerability can be considered either as economic vulnerability or ecological vulnerability. $4 / 5$

In the next sections, we consider three successive issues:

_ $\quad$ why economic vulnerability matters, particularly in small countries?

- $\quad$ how to design an economic vulnerability index for comparing SIDS and LDCs?

- $\quad$ what are the implications for international cooperation policy, and in particular, how the economic vulnerability index can be used for identifying LDCs and for aid policy?

manage instability, depends on the policies pursued. Exposure to shocks is more ambiguous: it is mainly a structural factor, but is also dependent, to some extent, on policy and this is all the more evident the longer the period considered.

4 The most comprehensive attempt to build an 'environmental vulnerability index' was undertaken by SOPAC (South Pacific Applied Geoscience Commission) (cf. Kaly et al. 1999). In May 1999, the CDP considered several available indicators (the Commonwealth Secretariat composite vulnerability index, the Caribbean Bank economic vulnerability index and the SOPAC environmental vulnerability index), before proposing a new and relatively simple index of economic vulnerability (UN 1999). In 2000, assessing the implementation of the outcome of the Barbados Conference, the GA (A/55/185) presented its own review of the several attempts to build a vulnerability index 'for small island developing states', a review which, to a large extent, focused on environmental issues

5 The same ambiguity is evident in the concept of sustainable development which covers both sustainability of economic growth and sustainability of environment since the depletion of natural resources may threaten growth as well as the environment. 


\section{Why vulnerability matters, particularly in small countries?}

This section summarizes the reasons why economic vulnerability may be detrimental to development, particularly in small countries (for a more extensive review, see Guillaumont 2006). Here we refer to a dynamic definition of vulnerability - the risk of economic growth being clearly and extensively reduced by shocks (or the risk of the long-term average rate of growth being reduced by shocks). 6 It is a handicap to growth. Another somewhat broader dynamic definition is the likelihood of negative and lasting effects of shocks on poverty reduction, either due to their impact on growth or direct effect on poverty.

We examine the links between vulnerability and growth according to the three main components of vulnerability explained above (shocks, exposure and resilience), and then add some few comments on the direct effects on poverty.

\subsection{Shocks: the negative impact of instability on growth}

\section{Focusing on instability and in particular on 'primary instabilities'}

There is not much debate about the negative impact of 'one-sided' natural shocks such as earthquakes, typhoons or floods. The damage is often huge, first in terms of the number of deaths, and second in the destruction of physical capital, and the debate revolves about the measurement of the size of these losses. But when the shocks are 'two-sided' (up-and-down cycles) - as many, particularly external, shocks are-their overall impact may be less clear. Depending on the measurement method used, the respective effects of positive and negative shocks tend to equalize. The very nature of instability is a succession of booms and slumps (of export prices, external demand, rainfall, etc.). This is why we consider here mainly the impact of instability or volatility rather than the impact of separate shocks, and it needs to be shown that the impact of these successive up-and-down cycles is not neutral. Their impact may result either from an asymmetry of ex post reaction to positive and negative shocks (even their time profile may not be symmetrical) or from the uncertainty generated by previous cycles. Thus, there are both ex post and ex ante effects of instability (as Gunning 2004 clearly underlines). Ex post effects may be easier to indicate than the ex ante ones, as these depend on a perception of risk. Thus, most measures used in cross-section literature rely ex post concepts.

Two empirical studies offer a test for macro vulnerability, considering the instability of growth but without a specific and separate examination of its main sources. One is the well-known study by Ramey and Ramey (1995). They show a significant link between the instability of the rate of economic growth and the average rate of growth itself (testing exogeneity of the instability). But this instability can also be due to structural factors and policy factors, which is why the volatility of growth cannot be an

6 At first glance vulnerability (with regard to growth) may appear simply as the opposite of the sustainability of growth, a concept used even more extensively: the more vulnerable a country, the less sustainable its growth, ceteris paribus. But the sustainability of growth depends not only (negatively) on the vulnerability to shocks, but also results from other permanent factors, such as the rate of human and physical capital accumulation, and the preservation of natural resources. 
approximate indicator of structural vulnerability (cf. infra). ${ }^{7}$ Another recent and systematic attempt to assess the link between output volatility and growth is by Hnathovska and Loayza (2004), who present findings of both a higher sensibility of growth to volatility in low-income countries and a higher impact of volatility over the last two decades than during the previous ones. The authors also show that volatility is more detrimental when institutions are poor (through a multiplicative variable), but do not assess the impact of structural vulnerability as such. 8

The effects of export instability, a main source of structural vulnerability in developing countries, have been examined over the years in the literature with growth regressions. There now seems to be a consensus emerging from several studies to conclude that export instability (or in some studies, terms of trade instability) has a negative effect on growth.9 More significant effects are noted when the (positive) effect of export growth and the (negative) effect of export instability are tested simultaneously and when the export instability (size of the shocks) is either weighted by the average export to GDP ratio for the period (Guillaumont 1994; Combes and Guillaumont 2002) —a ratio which, ceteris paribus, is the higher the lower the population size, or is an instability of the export to GDP ratio itself (Dawe 1996). Thus, the exposure to shocks is taken into account.

The effects of export-earnings instability are not the only kind of instability that have been tested. Guillaumont, Guillaumont Jeanneney and Brun (1999) estimate the influence of several primary instabilities, mainly exogenous, on the rate of growth. These authors argue that these instabilities, significantly higher in Sub-Saharan Africa than in other developing countries, may have been a major factor in the region's slow growth rate during the 1970s and 1980s. This is evident in the instability of the terms of trade, weighted by the average export to GDP ratio, or that of the real value of exports, similarly weighted, the instability of the agricultural value added (weighted by the average share of agricultural value added in GDP) and political instability. The first and the third factors appear to have a significant effect on growth. The exception is the agricultural value added. However, in another study, instability of both real value of exports and agricultural value added (unweighted here) appears to be significant (Guillaumont and Chauvet 2001). In a recent study, Miguel, Satyanath and Sergenti

7 Without attempting to distinguish between vulnerability resulting from structural factors or from policy sources, Rodrik (1999) also tests a negative influence on the change in the rate of growth between two 15-year periods of a multiplicative index of 'conflict', which multiplies an index of 'shocks' by an index of 'latent social conflict' (the ethnolinguistic fragmentation index or a Gini coefficient of income inequality), then by an index of the quality of conflict management institutions (namely, the lack of democracy or the quality of governmental institutions, as measured by Knack and Keefer 1995). Introduced alternatively, each of these appears highly significant. Rodrik also tests the respective effects of trade 'shocks' and of either an exposure index or an index of the capacity to cope.

8 They check the exogeneity of growth volatility through instrumental, mainly policy, variables.

9 See, for instance, Bleaney and Greenaway (2001); Glezakos (1984); Gyimah-Brempong (1991); Fosu (1992, 2002); Guillaumont (1994); Lutz (1994); Dawe (1996); Guillaumont, Guillaumont Jeanneney and Brun (1999); Combes and Guillaumont (2002); Mendoza (1997) and the review of the literature by Araujo Bonjean, Combes and Combes Motel (1999). 
(2004) examine the impact on growth of rainfall variations in African countries during 1981-99 and on the subsequent likelihood of civil conflict.10

\section{Instability channels to growth}

The effect on factor productivity is greater than on investment. A large part of the literature on the effects of export instability is devoted to its effects on savings, and these are ambiguous. Instability, on one hand, has long been assumed to enhance precautionary savings (Knudsen and Yotopoulos 1976), an assumption mainly relevant for private savings, and dependent on the degree of risk aversion, as shown by Mendoza (1997). On the other hand, instability may also generate ratchet effects mainly on public consumption. It can be a deterrent to private sector investment because of the perception of risk, as Aizenman and Marion (1999) argue. This is not the case with the public sector, which is often pushed to invest in boom periods, possibly with the help of procyclical borrowing, resulting in higher public indebtedness. Not surprisingly, the net result on the overall rate of investment is ambiguous, at least in its composition.

In contrast, the effects of instability on productivity growth are clearly negative and are a disincentive to GDP growth, as evidenced by several studies.11 In the cross-section growth regressions mentioned earlier, instabilities-either the so-called 'primary instabilities' (Guillaumont, Guillaumont Jeanneney and Brun 1999) or instability of the rate of growth (Ramey and Ramey 1995) - essentially reduce the total factor productivity growth rate. In fact, instability of the terms of trade appears to increase, rather than reduce, the rate of investment (Guillaumont, Guillaumont Jeanneney and Burn 1999) which makes the effect on the growth residual alone stronger than the total effect on growth.12

Instability is channelled through intermediate economic instabilities. Guillaumont, Guillaumont Jeanneney and Brun (1999) test the hypothesis that primary instabilities (terms of trade, agricultural production, political instability) influence growth through two important intermediate channels, namely, instability of the rate of investment and of relative prices. These two intermediate instabilities have negative effects on growth and are related to policy which is weakened in this manner by structural vulnerability.

First, instability of the rate of investment-curiously neglected in the literature-is a factor of lower average capital productivity. As a result of the declining marginal productivity of investment, the gain in total output from a high level of investment is smaller than the loss resulting from a low investment level. This effect, illustrated

10 Actually the aim of their paper is to test the impact of negative growth shocks on the likelihood of civil conflict, and it only uses rainfall variations as an instrumental variable for economic growth.

11 Growth regressions on instability or vulnerability indicators either include or exclude the rate of investment in addition to other control variables. When the rate of investment (investment to GDP ratio) is included, the coefficients of the instability or vulnerability indices express only their impact on the growth residual, whereas when it is excluded, the coefficient is assumed to assess their total effect, both through the rate of investment and the growth of factor productivity.

12 Similar results of the effects of export instabilities are observed by Guillaumont (1994) and Dawe (1996), who underline the effects through the growth residual rather than the rate of investment. These instabilities are 'weighted' by the export to GDP ratio (cf. infra). 
during boom periods by projects that are oversized, under-prepared and of limited productiveness, mainly concerns public investment.

The second intermediate instability, i.e., of the relative prices, proxied by the instability of the real effective exchange rate (REER), also appears to have a strong negative effect on the rate of growth. It is assumed to blur market signals and induce a misallocation of investment. This negative effect of the REER instability or volatility has also been presented in several papers (Aizenman and Marion 1999; Ghura and Grennes 1993; Serven 1997; Guillaumont, Guillaumont Jeanneney and Brun 1999).

Instability of real producer prices - whether due to macro policy resulting from REER instability or the passing of world agricultural prices fluctuations to farmers-is generally considered to be a factor in the lower average agricultural output, noticeably through its effects on the adoption of new technique.13 At a macro level, the effects of real producer prices instability on agricultural production growth have also been significantly tested in a sample pooling several products in a number of countries (Guillaumont and Combes 1996; Boussard and Gérard 1996; and Subervie 2006 for the effects of real border prices instability).

Thus it seems that external instability induces negative effects through shifts in the rate of investment and in the real exchange rate, either via its impact on public finance when retained at the government level or at the producer level when price fluctuations are passed through to producers.

Primary instabilities are high in both the SIDS and LDCs. Intermediate instabilities are high mainly in LDCs. Average and median values for both groups are given in Appendix Tables A5 and A6. Agricultural production and export instabilities (primary instabilities) have been relatively high for both groups during the past decades in comparison to other developing countries. These high primary instabilities in the LDCs have been channelled more clearly to (intermediate) investment and real exchange rate instabilities than in the SIDS, where higher and similar investment instabilities are observed, whereas real exchange rate instabilities are significantly higher in the LDCs (compared to other developing countries), and significantly lower in SIDS (again in comparison to other developing countries). This might be a reflection of the small relative share of non-traded goods in the SIDS, suggesting different channels of transmission for primary instabilities.

Instability is also channelled to growth through political instability. The primary instabilities, and the induced intermediate ones, are a factor in political instability and civil war, and through these, often tragic, events, also a significant factor of the slower growth. Some recent studies have examined the economic factors influencing these events, the results of which can be re-interpreted or modified when economic instability is taken into account. For instance, Collier and Hoeffler (2004) observe a higher risk of civil war in countries where primary commodities constitute a large share of exports. They explain this relationship mainly as the rent-seeking behaviour of rebels and their easier access to finance. Another reasonable assumption is that the instability of exports,

13 Newbery and Stiglitz (1981); see also UN (2001) for a review of studies on the impact of risk on agricultural productivity. 
higher if exports are primary, exacerbates the frustration. When the instability of exports, weighted by the openness rate is introduced in the Collier-Hoeffler conflict occurrence model, not only does the coefficient of determination increase significantly, but also the share of primary commodities in exports becomes insignificant (Guillaumont et al. 2005). Other exogenous shocks may have similar effects on the risk of conflict. For example, to examine the impact of civil war on growth Miguel, Satyanatah and Sergenti (2004) instrument civil war by rainfall instability, which is then shown to be a significant factor of it.

Moreover, political instability, according to several definitions, appears to be higher in the LDCs than in other developing countries, which is not the case for SIDS compared to non-SIDS.

\subsection{Exposure: major influence of country size}

A main structural factor in greater exposure to exogenous shocks is, of course, the smallness of a country. The size of a country can be measured several ways, the most meaningful of which is the number of inhabitants. In some cases (possibly with regard to natural shocks) area size could be a more relevant measure of the exposure to shock, but for assessing the main economic consequences of the size of a country independently from its income per capita, the most common measure is its population.

The vulnerability issue is confronted with the old and renewed debate on the consequences of the size of nations.14 Naturally country size has many consequences, not all of them related at first glance to vulnerability, as for example, scale economies in many sectors of activity, industry as well as government (the unit costs of public administration are expected to be higher in smaller countries). However, when investigating the channels through which size matters for development, the links with vulnerability become clear. There are at least three main channels (or intermediate variables) through which small size influences exposure to vulnerability: (i) trade intensity, (ii) government size and (iii) social cohesion.

The first variable-exposure to external shocks - is well-reflected by the export to GDP ratio. The smaller the (population) size, the higher (ceteris paribus) the trade to GDP ratio (and the more 'dependent' the economy). Country size is the main structural factor determining the trade to GDP ratio, next are the main determinant of 'natural openness' and the main factor to be neutralized if an index of 'openness policy' is drawn from the observed ratios (Guillaumont 1989, 1994). It is clear that the larger the share of exports in GDP, the greater the impact of a given export shortfall. This is why a better estimation of the impact of export instability (and of export growth as well) is obtained when the export instability variable (as well as export growth) is multiplied by the export to GDP ratio, i.e. when it is a 'weighted' instability. While natural openness, reflected mainly by smallness, increases exposure to trade shocks and subsequently the

14 See recent work by Alesina and Spolaore (2004) and Winters and Martins (2004). 
negative effect on growth, a policy of openness is not only a positive factor of growth, but also one of greater resilience (Guillaumont 1994; Combes and Guillaumont 2002). 15

Moreover, the diseconomies of scale associated with smallness result in greater difficulties to diversify at low cost. As a consequence, in adopting protectionist measures, small low-income countries face a higher risk of implementing inefficient or costly policies. For the same reason, a global protectionist trend is likely to be more damaging for small countries. Alesina and Spolaore (2004) test this effect in a crosssection growth regression through a multiplicative variable of the (log of) population and openness. The coefficient of this multiplicative variable is found to be significantly negative, while the coefficient of each of the two variables added independently to the regression is significantly positive.

Another reason why smallness is considered to be a factor of slower growth is its assumed impact on the size of government. The assumption of a (negative) relationship between (population) size and the relative size of government activities is successfully tested by Alesina and Spolaore (2004). An interpretation is given by Rodrik (1998) who argues that a high trade-to-GDP ratio (related itself to population size) leads to an extension of the role of the state in efforts to provide more insurance to its citizens. The relationship can also be linked to the stronger effect of public revenue instability on public consumption. If large-scaled government activities induce higher costs, this may again be the source of vulnerability resulting from smallness, and thus likely to hinder growth.

Third, country (population) size may impact on vulnerability and growth through social cohesion. Smallness may have the advantage of allowing greater social cohesion, i.e., less ethnic, linguistic or religion fragmentation. If social fragmentation is a negative growth factor and if fragmentation increases with population size, then smallness is an advantage, not a handicap. It needs to be noted that fragmentation as a handicap is not unrelated to vulnerability: it is assumed to negatively impact on growth because this structural factor influences the exposure or resilience to shocks (Rodrik 1999). Reality may be more complex, and several studies indicate non-linear relationships where linear ones are assumed. In particular social polarization, rather than social fragmentation, may be a handicap (and a factor of vulnerability) (Arcand, Guillaumont and Guillaumont Jeanneney 2002). Furthermore, polarization does not increase with population size, but rather decreases with size (at least beyond a low threshold). 16 Also for same reason, smallness may appear to enhance, not lower, vulnerability. 17

15 Let us add that with regard to natural shocks or disasters, insofar as they generally concern specific groups of the population, the larger the population, the smaller the aggregate exposure: in a large country, climatic shocks are likely to affect only a small part of the population.

16 Even the assumption of a negative correlation between population size and other linguistic fragmentation is debatable: when fragmentation is explained by the size of both the population and area, the coefficient of population size is significantly negative, while that of area is (significantly) positive. Since the absolute values of the coefficients are similar, it means that fragmentation decreases with population density (internal work in process at CERDI).

17 The greater social cohesion of small islands is also discussed by Helleiner (1996). 
Nevertheless, as indicated by several cross-country regressions, when appropriate control variables are used, the (log of) population size is a significant positive factor of growth (Alesina and Spolaore 2004; Bosworth and Collins 2003; Guillaumont and Guillaumont 1988; Guillaumont and Chauvet 2001; Milner and Weyman-Jones 2003) and a negative factor of export instability (Easterly and Kraay 2000). The observation that smallness hampers growth may be due to higher vulnerability, scale diseconomies or a combination of both.

Other factors of exposure to shocks are to be considered in addition to smallness of population size. These are related to the structure of the economy and the location of the country, as primary economies and remote countries are more exposed to external and natural shocks. The extent of country exposure is examined in the next section. Let us note here that as in the case of smallness, remoteness is a structural handicap not only because it is a factor of vulnerability 18 but also because distance remains an important obstacle to trade in spite of decreased transport costs (Brun, Guillaumont and de Melo 1999; Brun et al. 2005; Carrère and Schiff 2004).

\subsection{Resilience: policy, human capital and the poverty trap}

\section{Policy, shocks and resilience}

First, policy is weakened by structural vulnerability: overall instability of income transmitted to public revenue is a factor of public deficit and indebtedness, of instability and low productivity of public investment, of real exchange rate instability, etc. Policy variables are the intermediate instabilities that transfer primary instabilities to growth. This hypothesis is supported by the inclusion of a vulnerability indicator in a model where the explained variable is a composite indicator of macro policy (Guillaumont and Chauvet 2001). Also the effect of primary instabilities on political instability was noted above. Long-run effects of primary instabilities can also be expected to impact on the quality of institutions, but this issue remains open.

Nevertheless, policy is a major determinant of resilience. Structural vulnerability has an impact not only on the quality of economic policy, but its direct effects (on growth) also depend on policy. The main factors of resilience with regard to shocks are policy and institutions, in other words, the capacity of a country to cope effectively with exogenous shocks. This is why structural vulnerability needs to be distinguished from overall vulnerability, which includes an autonomous policy component essentially through the resilience. Indeed, institutions and policy themselves are influenced by other far-reaching factors, as Acemoglu et al. (2003) argue, in an explanation of their impact on the volatility of growth and the occurrence of crises.

One important policy-related element of resilience is the capacity of a country to maintain an appropriate level of competitiveness. Even if it increases a country's exposure to external shocks - as also small size does but only more significantly (natural openness)—outward-looking policy enhances its resilience. It means that in the growth regressions, the smaller the absolute value of the (negative) coefficient of the (weighted) export or terms of trade instability, the more outward-looking is the policy

18 The relevance of remoteness for vulnerability has been underlined by Encontre (1999). 
(Guillaumont 1994; Combes and Guillaumont 2002). Thus three effects of a more open trade policy can be identified: (i) the well-known positive effect of the growth of exports, the negative effect of the increased exposure to instability (the export-to-GDP ratio weighting the export instability), and the positive effect of a smaller impact of a given export instability, which means greater resilience. As argued in the last part of the paper, foreign aid can be another important factor of resilience.

\section{Human capital, resilience and the poverty trap}

Another important factor of resilience is the level of human capital. The capacity to react to shocks - whether through appropriate policy, the search for competitiveness, or the adaptation of activities - depends on the level of education and health. It appears that the lower the level of human capital, the higher impact of structural economic vulnerability on growth. In other words, vulnerability and weak human capital reinforce each other (Guillaumont 2007a): this may be considered as the empirical support on the rationale of the LDCs category, which defines as low-income countries as being disadvantaged by structural weakness (high vulnerability) and low level of human capital. And because of this compounded handicap, they are likely to be locked in a poverty trap.

This characteristic clearly distinguishes the LDCs from the SIDS. The small size of the SIDS makes them often highly vulnerable, but with better resilience because the level of human capital is on average higher than in the LDCs. In fact, this country group has been able to grow faster and to reach a higher level of income per capita.

\section{More on poverty effects of structural vulnerability}

Instability from faltering growth has deleterious consequences on the pace of poverty reduction. Apart from its effects on growth, it also has direct social effects for two reasons. First, there is a feeling of frustration that is generated by income shortfall after a period of a rapid expansion that creates new needs and exaggerated expectations. This is illustrated above by the risk of civil war or crime. The other reason is due to poverty traps, linked to the asymmetry of reactions of health, education, and employment to income fluctuations. Insofar as instability lowers growth, it deters the reduction of poverty normally expected from growth, but in a given average rate of growth also induces an anti-poor bias.

First, income instability lowers child survival. Probably the best single indicator of the social development in low-income countries is child mortality under five, made available through demographic and health surveys that have been extended by WHO. Child mortality is a sensitive indicator, and is likely to reflect the strong asymmetric effect that can be expected from income instability. If a rise in mortality results from an income shortfall, it will not be compensated in future periods with an equal income increase. Also, due to the existence of a lower limit to child mortality, the best functional form, where the dependent variable is expressed as a logit (Grigoriou and Guillaumont 2003), implies an asymmetry in the up and down effects of income variations for the relevant range of mortality values. Tested with an GMM, with observations every five years from 1980 to 2000, the effect of previous income instability on child survival appears to be significantly negative (Guillaumont 2006; Guillaumont, Korachais and Subervie 2006). 
Second, income instability delays poverty reduction. When we introduce the macro vulnerability concern in the burgeoning cross-country research on the determinants of the level and evolution of poverty, 19 it appears as a neglected factor. Until recently, the main concern has been the assessment of the growth and inequality elasticities of poverty,20 but without a similar concern for the effects of income instability on poverty reduction (Guillaumont 2006; Guillaumont and Korachais 2006).21 A reasonable assumption, however, is that income instability pushes people into a poverty trap (the poor encountering health problems, children leaving school, workers exiting the labour market, etc.) so that a rise in average income has less effect on poverty reduction than a fall in income (see, for instance, de Janvry and Sadoulet 2000 in the context of Latin America). This effect is expected to lower the absolute level of the average growth elasticity of poverty, and/or to increase poverty independently of income growth and inequality change: income instability must then be introduced both additively and multiplicatively with income growth. Measuring poverty change through the log of the headcount index of poverty in a sample of ten-year spells and controlling for the rate of growth of income per capita and initial level of poverty, we obtain significant coefficients for the impact of income instability on poverty. This effect corresponds to an increase in inequality which is captured only partially by the change in the Gini coefficient (another control variable). 22 It is worth recalling that in addition to this direct growth impact, volatility reduces the average rate of growth. Indeed, stability is good for growth, which is also 'good for the poor', but stability also makes growth better for the poor. Stability of growth makes it pro-poor.

\section{How the SIDS and the LDCs compare when a structural economic vulnerability index is designed?}

An indicator is needed to compare the structural vulnerability of LDCs and SIDS. Since the indicator is to be applied to both categories, we use the economic vulnerability index (EVI) which was initially designed and subsequently revised by the CDP.23 After reviewing the rationale of this choice, we compare the two groups of countries with regard to their shock components, exposure components according to the EVI index, the EVI itself, and finally with respect to resilience elements not included in EVI.

19 These have been made feasible by the extension of comparable datasets at the World Bank.

20 See Adams (2004) for a recent illustration.

21 Guillaumont Jeanneney and Kpodar (2005), however, examine the effects of financial instability on poverty.

22 Consistently with the idea that instability increases inequality, as found by Breen and Garcìa-Peñalosa (2005).

23 There were several attempts earlier to propose a vulnerability index (in particular Briguglio 1995; Atkins, Mazzi and Ramlogan 1998; Crowards 1999), but these were not appropriate for the purpose of LDCs identification, as noted by the CDP (UN 1999). An overview can be found in Briguglio and Kisanga (2004). For a general discussion of the topic, see Guillaumont (2007). 


\subsection{Choosing an index: EVI}

Here we refer to the economic vulnerability index (EVI), a composite index set up and applied by the CDP in 2000 as a criterion for the identification of LDCs. It was applied in 2003 and 2006 (UN 2000, 2003, 2006). Revisions were made before the two last triennial reviews of the LDCs list (see UN 2005, and the recommendations presented in Guillaumont 2004a, 2004b, 2006). And thanks to the collaboration between the UN DESA and CERDI, a retrospective EVI has been calculated covering three decades and is accorded with EVI's last revision in 2006 (Guillaumont 2007b). The present EVI is a composite index calculated from seven component indices, made up of four shock indices and three exposure indices. Using an arithmetic averaging, equal weight is given to the sum of shock indices and the sum of exposure indices. In the shock indices, equal weight is given to natural and external shocks, while in the exposure indices equal weight is given to population size and to the total of other indices. Naturally, there are several other ways, some possibly more logical, how these component indices can be weighted and averaged (Guillaumont 2006, 2007a), but the method adopted in EVI by the CDP has been chosen for reasons of simplicity and transparency.

Here we consider a composite index rather than a single one, such as the growth volatility, commonly used in econometric works. The volatility or instability of the rate of growth of income (per capita) reflects ex post macro economic instability which depends on exogenous shocks and structural factors of exposure, but also on policy factors, either as a reaction to shocks or as autonomous policy shocks. There is clear empirical evidence of the influence of policy factors on growth volatility (Easterly, Islam and Stiglitz 2001; Combes et al. 2000)24, and thus growth rate volatility cannot be considered a good synthetic indicator of structural vulnerability. Moreover if costly insurance or compensatory mechanisms are at work, the negative impact of shocks on growth does not necessarily involve growth instability. Nevertheless, growth volatility, even though showing some decline in the 1990s, is high in the developing countries. And it has been higher in the SIDS as well as in the LDCs, respectively compared to other developing countries. The relative position of the SIDS and the LDCs has changed over the decades (volatility higher in the SIDS during the 1980s, but the situation reversing in the 1990s).

\subsection{Shocks faced by the LDCs and the SIDS: permanently high}

\section{Natural shocks}

Climatic and other natural shocks are a main source of vulnerability in many developing countries and these cover a large variety of disasters: earthquakes, typhoons or hurricanes, floods, droughts, insect invasions, etc. An indicator of the risk of natural catastrophes might be the frequency of such events, measured over a long period of time. But as evidenced by the recent Asian tsunami, the most severe and exceptional

24 For instance, Easterly, Islam and Stiglitz stress the negative effect (up to a point) of financial depth and the positive effect of openness on volatility. More specifically, with regard to the effects of openness, Combes et al. 2000 find that structural vulnerability (depending on structural factors, including population size) makes growth more unstable, whereas outward-looking policy has the opposite effect. Bleaney and Fielding 2002 examine the impact of the exchange rate regime on output volatility in addition to the impact of exogenous factors such as instability in the terms of trade. 
disaster does not comply to any measurable probability. The potential negative impact of these very different catastrophes differs from one to the next, even within same type of disaster. Measuring the resulting economic losses in all the developing countries concerned seems impossible. A better approach would be to take the number of people affected, if known, but even then different people may be affected with varying severity. Indicators of the average proportion of the population affected can be used specifically with regard to the way the population is affected (killed, displaced ...). 25 The percentage of population displaced due to natural disasters (homeless index) has been retained as a component of EVI since 2003 when comparable data became available.

Due to this data problem and to the fact that not all natural shocks (as for instance recurrent droughts in Sahelian countries) are registered as 'disasters', another proxy was needed. The answer was the instability of agricultural production measured with regard to its trend value. The trend of agricultural production, if significantly measurable, can be assumed to depend mainly on a country's economic policy and other permanent factors. However, fluctuations around the trend can be hypothesized to be reflection of the occurrence and severity of natural shocks, because these are likely to affect agricultural production. 26 This is why this indicator was retained as a component of the EVI.

Both in the LDCs and SIDS, the homeless index has been significantly higher than in the other developing countries (for all periods). Furthermore, it has been higher in the SIDS than in the LDCs, albeit not significantly higher over the last decade (see Appendix Table A4). The agricultural instability index has also been high in both groups, but significantly higher only in the SIDS during the first two decades, whereas it was slightly lower in the SIDS during the last ten years (see Appendix Table A5). This implies that the difference between the two country groups with regard to these two indices has disappeared during the 1990s.

These previous two measures of natural shocks, which are not correlated, are only complementary proxies of the size of the natural shocks likely to affect growth prospects (likely to be aggregated in a single average level of natural economic shocks). They give a picture of the average size of past shocks which is only a proxy of the risk of similar future shocks. The risk of more severe or exceptional natural shocks, such as the December 2004 Asian tsunami, cannot be captured ex ante by any shock-probability index. It can only be reflected ex post in the measures here presented, and is more in the nature of a permanent damage, i.e., a structural handicap, than a risk. This difficulty suggests that more attention should be given to exposure indices.

Another caveat is needed. Instability indices are related to a trend or an average level. This one, even if predictable to some extent, can also reflect a structural handicap (e.g.,

25 The main source of the data is the Emergency Events Data base, compiled by the Center for Research on Epidemiology of Disaster (CRED) at the School of Public Health, Université Catholique de Louvain, data also given and supplemented in the IRC annual World Disasters Report. Based on these data sources, a picture of natural disasters in each of the LDCs can be found in UNDP (2001). A previous use of these data for the measurement of vulnerability is in Atkins, Mazzi and Ramlogan (1998).

26 We use this indicator in several earlier studies (cf. for instance, Guillaumont and Guillaumont 1988; Guillaumont, Guillaumont-Jeanneney and Brun 1999). 
lower rainfall levels in Sub-Saharan Africa), but is not retained here as a component of vulnerability.

\section{External shocks}

An indicator of trade shocks is given by the instability in real export proceeds surrounding the trend. It has to be applied to total exports of goods and services because shocks affect both types of exports, and often service exports in small (developing) countries account for a large part of total receipts. Some private transfers, such as migrant remittances, can also be included. It is assumed that for small countries this instability is structural, resulting from exogenous events such as fluctuations in world prices, in external demand and in domestic events that are not related to policy (e.g., climatic shocks). Of course, some fluctuations in the export volume trend may be a reflection of the instability of policy itself, but it can be assumed that policy has greater influence on the trend than export volume fluctuations. 27 However, the trend in the terms of trade, to a large extent, seems to be beyond the control of the country. When the terms of trade deteriorate (as when the sea level rises), it may be a handicap, without being an (unexpected) shock.

The export-instability indicator, although decreasing in both groups, appears to have been higher in the LDCs and the SIDS than in other developing countries. In particular, export instability has become more and more significant over the decades in the LDCs (due to a slower decrease), and gradually less in SIDS (due to a faster decrease), so that the average and median levels, which did not indicate much difference between these country groups during the 1970s, have become higher in the LDCs during the 1990s (see Appendix Table A6). And the level no longer shows a difference between the SIDS and other developing countries.

\subsection{Exposure to shocks: SIDS and LDCs highly exposed}

Four indicators are used to measure the exposure to shocks (see Appendix Table A3 and Tables A7 to A9:

27 The use of instability indices as components of a vulnerability indicator raises measurement problems. Instability is always relative to a reference or trend value. It is measured, for instance, by the average absolute deviation from the reference or trend value, or more commonly, by the variance of this deviation. A critical issue is then the choice of this reference value, in particular the estimation of the trend. A deterministic trend has long been adopted, for instance, in the export-instability literature. This was often inappropriate due to the possibility of non-stationarity of the series. On the other hand, the series may not be purely stochastic, and the reference value can be conveniently estimated from a 'mixed' function, combining a deterministic element and a stochastic element: this is how instabilities of exports and of agricultural production have been estimated in the EVI and which we retain in the next simulations. Several other measures are used in the empirical literature on issues that concern us. For instance, measurements of growth volatility generally use the standard deviation of the rate of growth (which may not be appropriate when the rate of growth is not stationary). Other works on volatility (in particular, aid volatility considered in the next section) use empirical filters such as the Hodrick-Prescott filter, in which a series is divided into 'cycle' and 'trend' components. In most cases these measures, intended to be internationally comparable, reflect only ex post instabilities, i.e., the deviations from a trend observed in the past, but not the risk variable perceived by economic agents, which would involve the specification of a model of anticipations, which could possibly differ among countries. 
i) Population size (in logs), based on the assumption that small size is an handicap due to vulnerability and other factors: it is clear that the SIDS, by their very definition, have a small average size, which is also the case with the LDCs, but to a lesser extent.

ii) Both in the SIDS and LDCs, the export concentration coefficient (as calculated by UNCTAD) is also higher than in other developing countries, but is significantly greater in the LDCs, and less significant in SIDS.

iii) The share of agriculture, forestry, fisheries is somewhat higher in other developing countries, higher also in SIDS, but significantly lower in SIDS than in LDCs (due to a larger share of services).

iv) The index of remoteness from world markets (adjusted for landlockedness) has been designed and calculated at CERDI and is used by the CDP for the measurement of EVI. It is significantly higher for the LDCs than for other developing countries, but curiously not so for the SIDS as a whole. This is due not only to the landlockedness adjustment in other countries, but also mainly because some SIDS are particularly remote (as in the Pacific), while other are not (in the Caribbean).

\subsection{Comparing synthetic indices}

We compare the synthetic indices from two datasets: the official dataset of the 2006 review of the CDP list of LDCs, and the tentative dataset of the 'retrospective EVI' mentioned above.

Averages from the 2006 review of LDC list

\begin{tabular}{lccc}
\hline & Shock index & Exposure index & EVI \\
\hline SIDS & 45 & 67 & 56 \\
LDCs & 52 & 55 & 53 \\
ALL LICs & 47 & 44 & 46 \\
All MICS & 37 & 47 & 43 \\
\hline
\end{tabular}

Averages from a retrospective database

\begin{tabular}{lccccc}
\hline & EVI & & & Shock index & Exposure index \\
\cline { 5 - 6 } & $1970-79$ & $1980-89$ & $1990-99$ & 44 & 64 \\
SIDS & 59 & 56 & 54 & 39 & 40 \\
Non-SIDS & 43 & 40 & 40 & 49 & 54 \\
LDCs & 53 & 52 & 51 & 35 & 41 \\
Non-LDCs & 43 & 39 & 38 & & \\
\hline
\end{tabular}

The results between the two datasets do not differ significantly and this allows us to draw a few observations:

- $\quad$ EVI is higher in the LDCs and in the SIDS compared to other developing countries; 
- $\quad$ the gap between LDCs and non-LDCs is increasing, while the gap between SIDS and non-IDS is decreasing;

- $\quad$ EVI is still higher in the SIDS than in the LDCs, but diminishing;

- $\quad$ while the exposure index is significantly higher in the SIDS than in the LDCs, the shock index is higher in the LDCs;

- $\quad$ the diminishing gap between the LDCs and the SIDS is due to the shock index, as the gap between the average exposure indices has not changed (see Appendix Tables 1 to 3);

- the slightly higher level of EVI in the low-income countries compared to middle-income ones is due to a somewhat higher shock index, while exposure index is lower.

\subsection{EVI and overall vulnerability: resilience of the SIDS}

The previous indicators have been related to structural vulnerability, reflecting the size of the shocks and exposure to them. Overall, vulnerability may also differ as a result of resilience. While we observe a higher structural vulnerability (EVI) in the SIDS than in the LCDS, we can also note lower growth instability, and higher average growth, which have promoted higher levels of GNI per capita in the small island developing states.

This higher resilience of the SIDS, as argued in section 3, seems to be mainly the result of higher human capital, which constitutes the major difference between the two country groups. The higher resilience can, of course, also be due to better average policy, but this fact is still a reflection of the level of human capital.

\section{Some policy implications of the vulnerability assessment}

Here we consider two main policy implications of the availability of the EVI. The more direct implication is related to the identification of the LDCs, the purpose for which the index has been created, and specifically the issue of SIDS exiting the LDCs list. The second issue, more indirect and general, is related to the use of EVI as an instrument in the design of aid policies.

\subsection{The LDCs graduation issue}

As noted in the introduction, EVI is one of the three criteria used by the Committee for Development Planning for the identification of the LDCs: GNI per capita and the human assets index (HAI), a composite index of health and education indicators, are the two other criteria. For inclusion in the list, a country must be characterized by three complementary criteria: being a low-income country, with a low level of human capital, and high vulnerability. The complementarity between the three criteria is based on the assumption of a combined effect of vulnerability and human capital on growth.

Exit or graduation from the list, and related rules were introduced only in 1991. These rules have been carefully designed to avoid premature departure from or movement in the list, such as countries, after exit, becoming again eligible for inclusion. Margins were imposed for the inclusion and graduation thresholds of the criteria. Exit eligibility 
is to be confirmed at two successive triennial reviews. And, more important, to be eligible for graduation, an LDC must show improvement in two of the benchmarks.

Since the creation of the list in 1991, only one country-Botswana-has graduated (1994). The graduation of Cape Verde and Maldives was ratified by the UN General Assembly in 2004 for implementation later. Samoa has been recommended by the CDP for graduation. Kiribati, Tuvalu and Vanuatu were given the first-round eligibility clearance by CDP in 2006, but this needs to be reconfirmed at the 2009 review before any recommendation is made.

It has to be noted that the LDCs mentioned above as possible graduates are SIDS. They have resisted the recommendation, and resistance by the Maldives was particularly strong, as is now from Samoa, based on the argument that these countries are highly vulnerable, as is evidenced by their EVI levels. Following this argument, some potential graduate countries have requested that an LDC could not be made to exit the list until it is no longer (highly) vulnerable, implying that (low) EVI would become a 'compulsory' criterion.

If this were to happen, it would mean that the asymmetry between the inclusion and exit criteria becomes even deeper. Inclusion is governed by poor ratings in three benchmarks, and graduation could be proposed only when there is improvement in all three criteria, instead of just one criterion (symmetry) or when two criteria no longer apply (present asymmetry). Such a solution would make graduation very unlikely, even for the SIDS that were rated as upper middle-income countries, and this would lead to inequitable treatment of the developing countries.

If certain developing countries have been able to sustainably achieve a significant rate of growth, as well as high levels of human capital, they are not likely to be locked in a poverty trap, as LDCs are assumed to be. And, even though they may be vulnerable, their high level of human capital is probably the cause of it. The vulnerability of these countries, however, is an issue of concern. This is why a smooth transition strategy for graduating countries has been proposed by the CDP and officially adopted by the UN General Assembly. Economic vulnerability should also be considered, through EVI, as a relevant parameter of aid policies.

\subsection{Dampening vulnerability by aid}

\section{Back to analytical basis}

Although negative factor of growth, structural vulnerability-sometimes captured only by (exogenous) export instability - has been found to increase the effectiveness of marginal aid (its marginal contribution to growth). And as has been put so strongly forward by Burnside and Dollar (2000) and the World Bank (1998), the effect is more significant than the quality of institutions and policy. In other words, aid dampens the negative effects of vulnerability on growth (Guillaumont and Chauvet 2001; Chauvet and Guillaumont 2004, 2007). These growth regression results are supported by the micro-macro analysis of the determinants of the rate of success of World Bank projects (Guillaumont and Laajaj 2006). It follows that aid is potentially more effective in vulnerable countries such as the SIDS and the LDCs. 
The current concern about high aid instability (see, for instance Bulir and Hamann 2003, 2005) is not contradictory with the above findings. First, it is not clear that aid is more often pro-cyclical than contra-cyclical with regard to the main exogenous flows (exports). Second, and more relevant, either pro-cyclical or contra-cyclical aid may have a stabilizing impact, still with regard to exports, captured by the difference between the export instability and the aid plus export instability. This stabilizing character is a significant factor of growth, confirming the previous results (Chauvet and Guillaumont 2007).

Moreover, aid, though its stabilizing impact, has a twin effect on poverty reduction. First, it enhances growth, which is a major factor in poverty reduction, and second, it also makes growth more pro-poor by making it more stable (Guillaumont 2006).

These briefly reviewed findings have three implications for aid policies.

\section{Structural vulnerability (EVI) among the criteria for aid allocation}

The first and easiest way to take economic vulnerability into account in the design of aid policies is to consider it as a relevant criterion of aid selectivity. The standard criteria for aid selectivity are the level of poverty (income per capita) and the quality of governance. 28 But these do not include vulnerability, which can be easily added for at least two reasons, and which could lead to significant changes in aid allocation (Amprou, Guillaumont and Guillaumont Jeanneney 2007). Both the LDCs and SIDS would benefit from the inclusion of a vulnerability measure.

First, as we have seen, aid effectiveness is increased by structural vulnerability. If aid is allocated according to vulnerability (among other criteria), it will be more effective. And this argument is also empirically (seemingly better) grounded than the similar argument used to support retaining governance as a criterion.

Second reason is equity. If we acknowledge that the goal of aid is to compensate for handicaps in order to promote equal opportunities/chances, then it is also legitimate to retain structural vulnerability — the handicap to growth—as a criterion for aid allocation.

Finally, a practical matter has to be kept in mind. Retaining vulnerability, possibly EVI, as an ex ante aid allocation criterion would lead to the immediate dampening of unforeseen shocks. This may not be as easy with the other modalities now briefly considered.

\section{Aid modalities to use aid as insurance}

As these views have been extensively examined in other papers (Guillaumont 2006; Guillaumont and Guillaumont Jeanneney 2003), we focus here only on the core arguments (see also Collier et al. 1999; Sarris 2003; Gilbert and Tabova 2005). The challenge is to compensate negative shocks quickly and to simultaneously promote good governance, avoiding moral hazard. The solution is to offer automatic compensation once the rules of management (particularly in the case of positive shocks)

28 The CPIA at the World Bank or any other index, such as ICRG or the Kaufman and Kraay index. See for instance, Collier and Dollar (2001, 2002); World Bank (2004, 2005). 
have been agreed and implemented ex ante. This would combine the delivery of needed resources and the strengthening of ownership, and could be achieved through debt service regulation (+/-) in accordance with the development of the terms of trade, or through a special fund for small indebted countries. Links between micro and macro variables need to be checked, to make the insurance scheme effective not only at the macrolevel, but also for the groups more severely affected by shocks, such as small farmers.

\section{Support to operations aimed at lowering instability and its impact}

This is a longer-term issue, as it involves structural transformation. Should its relative importance with respect to the SIDS be re-examined? Certainly not: we have seen, for instance, that the export concentration index has significantly decreased in the SIDS, more than in the LDCs. Any diversification policy has to balance costs and benefits. International support to promote regional integration will lower exposure and increase resilience in the LDCs as well as in the SIDS. It can thus be a major factor in reducing vulnerability and make growth more sustainable.

\section{Conclusion}

Structural economic vulnerability is a matter of concern, particularly for the SIDS and the LDCs, albeit in a different way for each group. Vulnerability can conveniently be captured through two elements: (i) the economic vulnerability index (EVI) designed at the UN by the Committee for Development Policy, and (ii) its shock and exposure components. This index is a suitable instrument to guide international development policies in two fields: the identification of LDCs, which are the low-income countries most severely affected by structural handicaps to growth. Economic vulnerability is a major disadvantage that needs to be considered in tandem with a low level of human capital. in order to be considered for inclusion in the LDCs list, in addition to meeting the vulnerability criterion, a country needs to comply with the stipulations of having a low income per capita and a low level of human capital. Consequently, once the income level of a country exceeds the low-income threshold and the country has a relatively high level of human capital, it is likely to be graduated from the list even though it may still be vulnerable.

The second field where the use of EVI is needed is the geographical allocation of aid. For reasons of effectiveness and equity, structural vulnerability can constitute as one of the relevant criteria of aid allocation; its application would favour vulnerable countries, LDCs as well as SIDS, even if the latter do not comply in the strictest sense with the LDCs qualifications. In the two country groups, structural vulnerability should seriously be taken into account, but not exclusively. The identification of LDCs cannot rely solely on vulnerability, and vulnerability cannot be the compulsory criterion for exiting the list of LDCs. Aid allocation cannot rely on vulnerability only. 


\section{References}

Acemoglu, D., S. Johnson, J. Robinson, and Y. Thaicharoen (2003). 'Institutional Causes, Macroeconomic Symptoms: Volatility, Crises and Growth'. Journal of Monetary Economics, 50 (1): 49-123.

Adams, Jr., R. H. (2004). 'Economic Growth, Inequality and Poverty: Estimating the Growth Elasticity of Poverty’. World Development, 32 (12): 1989-2014.

Aizenman, J., and N. Marion (1999). 'Volatility and Investment: Interpreting Evidence from Developing Countries’. Economica, 68 (26): 157-80.

Alesina, A., and E. Spolaore (2004). The Size of Nations. Cambridge, MA: MIT Press.

Amprou, J., P. Guillaumont, and S. Guillaumont Jeanneney (2007). 'Aid Selectivity According to Augmented Criteria’. World Economy, May (forthcoming).

Araujo Bonjean, C., J.-L. Combes, and P. Combes Motel (1999). 'The Economic Consequences of Export Instability in Developing Countries: A Survey’. CERDI Etudes et Documents. Clermont-Ferrand: CERDI.

Arcand, J-L., P. Guillaumont, and S. Guillaumont Jeanneney (2002). 'Ethnicity, Communication, and Growth'. CERDI Etudes et Documents. Clermont-Ferrand: CERDI.

Atkins, J., S. Mazzi, and C. Ramlogan (1998). A Study of the Vulnerability of Developing and Island States: A Composite Index. London: Commonwealth Secretariat.

Berg, A., and C. Patillo (1999). 'Are Currency Crises Predictable: A Test'. IMF Staff Papers, 46 (2): 107-13.

Bleaney, M., and D. Greenaway (2001). 'The Impact of Terms of Trade and Real Exchange Rate Volatility on Investment and Growth in Sub-Saharan Africa'. Journal of Development Economics, 65 (2): 491-500.

Bleaney, M., and D. Fielding (2002). 'Exchange Rate Regimes, Inflation and Output Volatility in Developing Countries'. Journal of Development Economics, 68 (1): 233-45.

Bosworth, B. P., and S. M. Collins (2003). 'The Empirics of Growth: An Update'. Brookings Papers on Economic Activity, 2: 113-207.

Boussard, J. M., and F. Gérard (1996). 'Price Stabilization and Agricultural Supply'. In M. Benoit-Cattin, M. Griffon, and P. Guillaumont (eds), Economics of Agricultural Policies in Developing Countries, vol. 2. Paris: Edition Revue Française d'Economie, 269-86.

Breen, R., and C. Garcìa-Peñalosa (2005). 'Income Inequality and Macroeconomic Volatility: An Empirical Investigation’. Review of Development Economics, 9 (3): 380-98.

Briguglio, L. (1995). 'Small Island States and their Economic Vulnerabilities'. World Development, 23 (9): 1615-32. 
Briguglio, L., and E. J. Kisanga (eds) (2004). Vulnerability and Resilience of Small States. Malta: Commonwealth Secretariat and Islands and Small States Institute of the University of Malta.

Brun, J-F., P. Guillaumont, and J. de Melo (1999). 'La distance abolie? Critères et mesures de la mondialisation du commerce extérieur'. In A. Bouet and J. Le Cacheux (eds), Globalisation et politiques économiques: les marges de manoeuvre. Paris: Economica.

Brun, J-F., C. Carrere, P. Guillaumont, and J. de Melo (2005). 'Has Distance Died? Evidence from a Panel Gravity Model’. World Bank Economic Review, 19 (1): 99101.

Bulir, A., and A. Javier Hamann (2003). 'Aid Volatility: An Empirical Assessment'. IMF Staff Papers, 50 (1): 64-89.

Bulir, A., and A. Javier Hamann (2005). 'Volatility of Development Aid: From the Frying Pan into the Fire?’ IMF draft working paper. Washington, DC: IMF.

Burnside, C., and D. Dollar (2000). 'Aid, Policies and Growth'. American Economic Review, 90 (4): 847-68.

Carrère, C., and M. Schiff (2004). 'On the Geography of Trade’. WB Policy Research Working Paper 3206. Washington, DC: World Bank.

Chauvet, L., and P. Guillaumont (2004). 'Aid and Growth Revisited: Policy, Economic Vulnerability and Political Instability’. In B. Tungodden, N. Stern, and I. Kolstad (eds), Toward Pro-Poor Policies-Aid, Institutions and Globalization. Washington, DC: World Bank/Oxford University Press.

Chauvet, L., and P. Guillaumont (2007). 'Aid, Volatilities and Growth Again'. Clermont-Ferrand: CERDI. Mimeo.

Collier, P., and A. Hoeffler (2004). 'Aid, Policy and Growth in Post-Conflict Societies'. European Economic Review, 48 (5): 1125-45.

Collier, P., and D. Dollar (2001). 'Can the World Cut Poverty in Half? How Policy Reform and Effective Aid Can Meet International Development Goals'. World Development, 29 (11): 1787-802.

Collier, P., and D. Dollar (2002). 'Aid, Allocation and Poverty Reduction'. European Economic Review, 46 (8): 1475-500.

Collier, P., P. Guillaumont, S. Guillaumont Jeanneney, and J. Gunning (1999). 'Reforming Stabex'. The World Economy, 22 (5): 669-82.

Combes, J.-L., and P. Guillaumont (2002). 'Commodity Price Volatility, Vulnerability and Development’. Development Policy Review, 20 (1): 25-39.

Combes, J.-L., P. Guillaumont, S. Guillaumont Jeanneney, and M. Combes (2000). 'Ouverture sur l'extérieur et instabilité des taux de croissance'. Revue Française d'Economie, 15 (1): 3-33.

Crowards, T. (1999). 'An Economic Vulnerability Index for Developing Countries, with Special Reference to the Caribbean: Alternative Methodologies and Provisional Results’. Barbados: Caribbean Development Bank. 
Dawe, D (1996). 'A New Look at the Effects of Export Instability on Investment and Growth’. World Development, 24 (12): 1905-14.

de Janvry, A., and E. Sadoulet (2000). 'Growth, Poverty and Inequality in Latin America: A Causal Analysis'. Review of Income and Wealth , 46 (3): 267-87.

Easterly, W., and A. Kraay (2000). 'Small States, Small Problems? Income, Growth, and Volatility in Small States'. World Development, 28 (11): 2013-27.

Easterly, W., R. Islam, and J. Stiglitz (2001). 'Shaken and Stirred: Explaining Growth Volatility'. In B. Pleskovic and N. Stern (eds), Annual Bank Conference on Development Economic. Washington, DC: World Bank, 191-213.

ECOSOC (various years). United Nations Economic and Social Council documentation. E/2000/L.29 and E/2005/L.52. Available at: www.un.org/ecosoc/docs/ resdec1946_2000.asp.

Encontre, P. (1999). 'The Vulnerability and Resilience of Small Island Developing States in the Context of Globalization’. Natural Resources Forum, 23: 261-70.

Fosu, A. K. (1992). 'Effect of Export Instability on Economic Growth in Africa'. The Journal of Developing Areas, 26 (3): 323-32.

Fosu, A. K. (2002). 'Economic Fluctuations and Growth in Sub-Saharan Africa: The Importance of Import Instability'. The Journal of Development Studies, 37 (3): 7184.

Ghura, D., and T. J. Grennes (1993). 'The Real Exchange Rate and Macroeconomic Performance in Sub-Saharan Africa'. Journal of Development Economics, 42 (1): 155-74.

Gilbert, C. L., and A. Tabova (2005). 'Can We Link Concessional Debt Service to Commodity Prices?’ GRADE Discussion Paper No. 8. Trento: University of Trento.

Glezakos, C. (1984). 'Export Instability and Economic Growth: Reply'. Economic Development and Cultural Change, 32: 615-23.

Goldstein, M., G. L. Kaminski, and C. M. Reinhart (2000). Assessing Financial Vulnerability. An Early Warning System for Emerging Markets. Washington, DC: Institute for International Economics.

Grigoriou, C., and P. Guillaumont (2003). 'A Dynamic Child Survival Function: Natural Convergence and Economic Policy'. CERDI Etudes et documents. Clermont-Ferrand: CERDI.

Guillaumont, P. (1989). 'Stratégie de développement et ouverture sur l'extérieur'. African Development Review, 1 (1): 40-57.

Guillaumont, P. (1994). 'Politique d'ouverture, exportation et croissance économique: les effets de la croissance et de l'instabilité des exportations'. Revue d'Économie du Développement, 1: 91-114.

Guillaumont, P. (2004a). 'A Revised EVI'. UN Document CDP/2004/PLEN/16, 31/03/2004. New York: UN. 
Guillaumont, P. (2004b). 'On the Economic Vulnerability of Low Income Countries'. In L. Briguglio and E. J. Kisanga (eds), Economic Vulnerability and Resilience of Small States. Malta: Formatek Malta, 54-71.

Guillaumont, P. (2006). 'Macro Vulnerability in Low-Income Countries and Aid Responses'. In F. Bourguignon, B. Pleskovic, and J. van der Gaag (eds), Securing Development in an Unstable World. Proceedings of the Annual Bank Conference on Development Economics, May. Amsterdam. 65-108.

Guillaumont, P. (2007a). 'Moving out of the Trap: The Least Developed Countries'. Economica (forthcoming).

Guillaumont, P. (2007b). ‘A Retrospective EVI: Methodologial Aspects'. CERDI Etudes et Documents. Clermont-Ferrand: CERDI.

Guillaumont, P., and L. Chauvet (2001). 'Aid and Performance: A Reassessment'. Journal of Development Studies, 37 (6): 66-92.

Guillaumont, P., and J.-L. Combes (1996). 'The Effects of Producer Price Trends and Instability on the Growth of Agricultural Exports: A Cross-section Analysis'. In M. Benoit-Cattin, M. Griffon and P. Guillaumont (eds), Economics of Agricultural Policies in Developing Countries. Paris: Edition de la Revue Française d'Economie, 287-300.

Guillaumont, P., and S. Guillaumont (eds) (1988). 'Stratégies de développement comparées zone franc et hors zone franc’. Paris: Economica.

Guillaumont, P., and S. Guillaumont Jeanneney (2003). 'Dampening Price Shocks'. In I. Bannon and P. Collier (eds), Natural Resources and Violent Conflict. Washington, DC: World Bank, 353-67.

Guillaumont, P., and C. Korachais (2006). 'Growth Instability against Pro-Poor Growth’. CERDI Etudes et documents. Clermont-Ferrand: CERDI.

Guillaumont, P., and R. Laajaj (2006). 'When Instability Increases the Effectiveness of Aid Projects’. WB Policy Working Paper 4034. Washington, DC: World Bank.

Guillaumont, P., S. Guillaumont Jeanneney, and J. F. Brun (1999). 'How Instability Lowers African Growth’. Journal of African Economies, 8 (1): 87-107.

Guillaumont, P., C. Korachais, and J. Subervie (2006). 'How Macroeconomic Instability Lowers Child Survival'. Paper presented at the UNU-WIDER on Health Equity, 29-30 September. Helsinki.

Guillaumont, P., S. Guillaumont Jeanneney, P. Jacquet, L. Chauvet, and B. Savoye (2005). 'Attenuating through Aid the Vulnerability to Price Shocks'. In F. Bourguignon and P. Jacquet (eds), Economic Integration and Social Responsibility. Washington, DC: World Bank.

Guillaumont-Jeanneney, S., and K. Kpodar (2005). 'Financial Development, Financial Instability and Poverty’. CSAE WPS/2005-08. Oxford: CSAE, University of Oxford.

Gunning, J. W. (2004). 'Why Give Aid?’ Paper presented at the Second AFD-EUDN Conference on Development Aid: Why and How?, 25 November. Paris.

Gyimah-Brempong, K. (1991). 'Export Instability and Economic Growth in Sub-Saharan Africa'. Economic Development and Cultural Change, 39 (4): 815-28. 
Helleiner G. K. (1996). 'Why Small Countries Worry: Neglected Issues in Current Analyses of the Benefits and Costs for Small Countries of Integrating with Large Ones'. The World Economy, 19 (16): 759-65.

Hnathovska, V., and N. Loayza (2004). 'Volatility and Growth'. WB Policy Research Working Paper No. 3184. Washington, DC: World Bank.

Kaly, U., L. Briguglio, H. McLeod, S. Schmall, C. Pratt, and R. Pal (1999). 'Environmental Vulnerability Index (EVI) to Summarize National Environmental Vulnerability Profiles’. SOPAC Technical Report 275.

Knack, S., and P. Keefer (1995). 'Institutions and Economic Performance: CrossCountry Test Using Alternative Institutional Measures'. Economics and Politics, 7 (3): 207-27.

Knudsen, O., and P. Yotopoulos (1976). 'A Transitory Approach to Export Instability'. Food Research Institute Studies, 15: 91-108.

Lutz, M. (1994). 'The Effects of Volatility in the Terms of Trade on Output Growth: New Evidence'. World Development, 22 (12): 1959-75.

Mendoza, E. G. (1997). 'Terms-of-Trade Uncertainty and Economic Growth'. Journal of Development Economics, 54 (2): 323-56.

Miguel, E., S. Satyanath, and E. Sergenti (2004). 'Economic Shocks and Civil Conflict: An Instrumental Variables Approach’. Journal of Political Economy, 112 (4): 72553.

Milner, C., and T. Weyman-Jones (2003). 'Relative National Efficiency and Country Size: Evidence for Developing Countries'. Review of Development Economics, 7 (1): $1-14$.

Newbery, D., and J. Stiglitz (1981). Theory of Commodity Price Stabilization: A Study in the Economics of Risk. Oxford: Clarendon Press.

Ramey, G., and V. Ramey (1995). 'Cross Country Evidence on the Link between Volatility and Growth’. The American Economic Review, 85 (5): 1138-51.

Rodrik, D. (1998). 'Why Do More Open Economies Have Bigger Governments?'. Journal of Political Economy, 106 (5): 997-1032.

Rodrik, D. (1999). 'Where Did All the Growth Go? External Shocks, Social Conflict and Growth Collapses’. Journal of Economic Growth, 4 (4): 385-412.

Sarris, A. (2003). 'Une assurance du prix des matières premières fondée sur le marché pour les pays en développement: vers une nouvelle approche'. Revue d'économie du développement, 2003 (1): 5-41.

Serven, L. (1997). 'Irreversibility, Uncertainty and Private Investment: Analytical Issues and Some Lessons for Africa'. Journal of African Economies, 6 (3): 229-68 (supplement).

Subervie, J. (2006). 'The Impact of World Price Instability on Agricultural Supply According to Macroeconomic Environment'. CERDI Etudes et documents. (forthcoming in Journal of Agricultural Economics). 
United Nations (1999). Vulnerability and Poverty in a Global Economy. Report of the Committee for Development Policy on the First Session. New York: UN.

United Nations (2000). Poverty Amidst Riches: The Need for Change. Report of the Committee for Development Policy on the Second Session. New York: UN.

United Nations (2001). The Costs of Poverty and Vulnerability. New York UN-DESA.

United Nations (2002). Capacity Building in Africa. Report of the Committee for Development Policy on the Fourth Session. New York: UN.

United Nations (2003). Local Developments and Global Issues. Report of the Committee for Development Policy on the Fifth Session. New York: UN.

United Nations (2004). Local Development and Global Issues. Report of the Committee for Development Policy on the Sixth Session. New York: UN.

United Nations (2005). Development Challenges in Sub-Saharan Africa and PostConflict Countries. Report of the Committee for Development Policy on the Seventh Session. New York: UN.

United Nations (2006). Overcoming Economic Vulnerability and Creating Employment. Report of the Committee for Development Policy on the Eighth Session. New York: UN.

UNDP (2001). 'Disaster Profiles of the Least Developed Countries'. Third UN Conference on Least Developed Countries, 14-20 May. Brussels.

Winters, L. A., and P. M. G. Martins (2004). 'When Comparative Advantage is not Enough: Business Costs in Small Remote Economies’. World Trade Review, 3 (3): 347-83.

World Bank (1998). Assessing Aid: What Works, What Doesn't and Why. New York: Oxford University Press.

World Bank (2004). Global Monitoring Report 2004-Millennium Development Goals: From Consensus to Momentum. Washington, DC: World Bank.

World Bank (2005). Global Monitoring Report 2005-Policies and Actions for Achieving the Millennium Development Goals and Related Outcomes. Washington, DC: World Bank. 


\section{Appendix Tables}

Appendix Table A1: Ex-post EVI

Appendix Table A2: $\quad$ Shock index

Appendix Table A3: Exposure index

Appendix Table A4: Homeless

Appendix Table A5: Agricultural instability

Appendix Table A6: Instability of exports, ex post

Appendix Table A7: Population

Appendix Table A8: Remoteness, ex post

Appendix Table A9: Share of agriculture, etc. in GDP

Appendix Table A10: Export concentration 
Appendix Table A1

Ex-post EVI

By groups of countries, by decades, 5-year periods and Wilcoxon tests

\begin{tabular}{|c|c|c|c|c|c|c|c|c|c|c|c|}
\hline Groups & Statistics & $1970-79$ & $1980-89$ & $1990-99$ & $1970-74$ & $1975-79$ & $1980-84$ & $1985-89$ & $1990-94$ & 1995-99 & $2000-04$ \\
\hline Developing countries & Moy & 46.8 & 44.2 & 43.5 & \multirow{4}{*}{0.0} & 47.3 & 44.9 & 43.4 & 44.0 & 42.6 & \multirow{4}{*}{0.0} \\
\hline Developing countries & Nbo & 122.0 & 122.0 & 122.0 & & 122.0 & 122.0 & 122.0 & 122.0 & 122.0 & \\
\hline Developing countries & $S d$ & 14.5 & 14.5 & 13.0 & & 14.8 & 14.6 & 14.2 & 13.9 & 13.6 & \\
\hline Developing countries & Median & 45.3 & 42.5 & 43.5 & & 45.7 & 43.5 & 41.9 & 43.3 & 42.0 & \\
\hline Least developed countries & Moy & 52.8 & 51.6 & 51.3 & \multirow{4}{*}{0.0} & 53.6 & 52.3 & 50.5 & 52.3 & 51.0 & \multirow{4}{*}{0.0} \\
\hline Least developed countries & $\mathrm{Nbo}$ & 50.0 & 50.0 & 50.0 & & 50.0 & 50.0 & 50.0 & 50.0 & 50.0 & \\
\hline Least developed countries & $S d$ & 14.1 & 13.7 & 11.7 & & 15.1 & 14.6 & 12.8 & 12.2 & 12.7 & \\
\hline Least developed countries & Median & 50.6 & 50.9 & 49.7 & & 51.3 & 51.0 & 48.1 & 52.0 & 49.5 & \\
\hline Non-least developed countries & Moy & 42.7 & 39.0 & 38.0 & \multirow{4}{*}{0.0} & 42.9 & 39.7 & 38.4 & 38.2 & 36.7 & \multirow{4}{*}{0.0} \\
\hline Non-least developed countries & Nbo & 72.0 & 72.0 & 72.0 & & 72.0 & 72.0 & 72.0 & 72.0 & 72.0 & \\
\hline Non-least developed countries & $S d$ & 13.4 & 12.7 & 11.1 & & 12.9 & 12.4 & 13.1 & 11.9 & 10.9 & \\
\hline Non-least developed countries & Median & 42.4 & 39.2 & 37.0 & & 42.1 & 38.7 & 37.3 & 36.8 & 35.4 & \\
\hline SIDS & Moy & 59.4 & 55.7 & 53.9 & \multirow{4}{*}{0.0} & 60.0 & 56.8 & 55.8 & 55.6 & 53.3 & \multirow{4}{*}{0.0} \\
\hline SIDS & $\mathrm{Nbo}$ & 31.0 & 31.0 & 31.0 & & 31.0 & 31.0 & 31.0 & 31.0 & 31.0 & \\
\hline SIDS & $S d$ & 13.6 & 13.7 & 11.1 & & 14.2 & 13.8 & 13.8 & 12.4 & 11.5 & \\
\hline SIDS & Median & 60.1 & 53.3 & 54.1 & & 59.1 & 55.4 & 53.7 & 55.5 & 53.0 & \\
\hline Non-SIDS & Moy & 42.5 & 40.3 & 39.9 & \multirow{4}{*}{0.0} & 43.0 & 40.8 & 39.1 & 40.0 & 38.9 & \multirow{4}{*}{0.0} \\
\hline Non-SIDS & Nbo & 91.0 & 91.0 & 91.0 & & 91.0 & 91.0 & 91.0 & 91.0 & 91.0 & \\
\hline Non-SIDS & $S d$ & 12.2 & 12.5 & 11.7 & & 12.4 & 12.6 & 11.7 & 12.1 & 12.3 & \\
\hline Non-SIDS & Median & 42.2 & 39.7 & 39.4 & & 42.3 & 40.3 & 38.5 & 39.5 & 37.4 & \\
\hline LDCs non-SIDS & Moy & 48.5 & 47.7 & 48.1 & \multirow{4}{*}{0.0} & 49.1 & 48.0 & 46.2 & 48.4 & 47.6 & \multirow{4}{*}{0.0} \\
\hline LDCs non-SIDS & Nbo & 38.0 & 38.0 & 38.0 & & 38.0 & 38.0 & 38.0 & 38.0 & 38.0 & \\
\hline LDCs non-SIDS & $S d$ & 11.3 & 11.1 & 10.2 & & 12.5 & 11.8 & 8.9 & 10.2 & 11.1 & \\
\hline LDCs non-SIDS & Median & 45.7 & 44.2 & 46.4 & & 46.1 & 45.2 & 45.3 & 47.7 & 45.3 & \\
\hline LDCs/non-LDCs & $\begin{array}{l}\text { Wilcoxonn-z } \\
\text { pvalue-z }\end{array}$ & $\begin{array}{l}-3.6 \\
0.000\end{array}$ & $\begin{array}{l}-4.5 \\
0.000\end{array}$ & $\begin{array}{l}-5.6 \\
0.000\end{array}$ & & $\begin{array}{l}-3.6 \\
0.000\end{array}$ & $\begin{array}{l}-4.3 \\
0.000\end{array}$ & $\begin{array}{l}-4.4 \\
0.000\end{array}$ & $\begin{array}{l}-5.6 \\
0.000\end{array}$ & \multicolumn{2}{|l|}{$\begin{array}{l}-5.6 \\
0.000\end{array}$} \\
\hline SIDS/non-SIDS & $\begin{array}{l}\text { Wilcoxonn-z } \\
\text { pvalue-z }\end{array}$ & $\begin{array}{l}-5.4 \\
0.000\end{array}$ & $\begin{array}{l}-4.9 \\
0.000\end{array}$ & $\begin{array}{l}-5.2 \\
0.000\end{array}$ & & -5.2 & $\begin{array}{l}-5.0 \\
0.000\end{array}$ & $\begin{array}{l}-5.2 \\
0.000\end{array}$ & $\begin{array}{l}-5.3 \\
0.000\end{array}$ & \multicolumn{2}{|l|}{$\begin{array}{l}-5.3 \\
0.000\end{array}$} \\
\hline \multirow{2}{*}{ SIDS/LDCs non-SIDS } & & & & & & & & & & \multirow{2}{*}{\multicolumn{2}{|c|}{$\begin{array}{l}-2.1 \\
0.032\end{array}$}} \\
\hline & pvalue-z & $\begin{array}{l}-3.5 \\
0.001 \\
\end{array}$ & $\begin{array}{l}-2.5 \\
0.020 \\
\end{array}$ & $\begin{array}{l}-2.2 \\
0.027 \\
\end{array}$ & & 0.003 & $\begin{array}{l}-2.5 \\
0.012 \\
\end{array}$ & 0.003 & $\begin{array}{l}-2.4 \\
0.014 \\
\end{array}$ & & \\
\hline
\end{tabular}

Source: CERDI (2006). 
Appendix Table A2

Shock index

By groups of countries, by decades, 5-year periods and Wilcoxon tests

\begin{tabular}{|c|c|c|c|c|c|c|c|c|c|c|c|}
\hline Groups & Statistics & $1970-79$ & $1980-89$ & $1990-99$ & $1970-74$ & $1975-79$ & $1980-84$ & $1985-89$ & $1990-94$ & $1995-99$ & $2000-04$ \\
\hline $\begin{array}{l}\text { Developing countries } \\
\text { Developing countries } \\
\text { Developing countries } \\
\text { Developing countries }\end{array}$ & $\begin{array}{l}\text { Moy } \\
\text { Nbo } \\
\text { Sd } \\
\text { Median }\end{array}$ & $\begin{array}{r}41.2 \\
122.0 \\
18.0 \\
39.6\end{array}$ & $\begin{array}{r}40.3 \\
122.0 \\
18.2 \\
37.0\end{array}$ & $\begin{array}{r}40.6 \\
122.0 \\
15.2 \\
38.8\end{array}$ & 0.0 & $\begin{array}{r}43.3 \\
122.0 \\
18.9 \\
42.3\end{array}$ & $\begin{array}{r}41.2 \\
122.0 \\
18.3 \\
38.2\end{array}$ & $\begin{array}{r}38.9 \\
122.0 \\
17.0 \\
36.9\end{array}$ & $\begin{array}{r}41.1 \\
122.0 \\
16.6 \\
39.6\end{array}$ & $\begin{array}{r}39.4 \\
122.0 \\
15.7 \\
37.9\end{array}$ & 0.0 \\
\hline $\begin{array}{l}\text { Least developed countries } \\
\text { Least developed countries } \\
\text { Least developed countries } \\
\text { Least developed countries }\end{array}$ & $\begin{array}{l}\text { Moy } \\
\text { Nbo } \\
\text { Sd } \\
\text { Median }\end{array}$ & $\begin{array}{l}46.2 \\
50.0 \\
18.7 \\
42.4\end{array}$ & $\begin{array}{l}47.8 \\
50.0 \\
19.6 \\
46.8\end{array}$ & $\begin{array}{l}49.0 \\
50.0 \\
15.4 \\
47.1\end{array}$ & 0.0 & $\begin{array}{l}48.8 \\
50.0 \\
20.5 \\
47.7\end{array}$ & $\begin{array}{l}48.5 \\
50.0 \\
19.6 \\
47.6\end{array}$ & $\begin{array}{l}45.9 \\
50.0 \\
17.6 \\
44.3\end{array}$ & $\begin{array}{l}50.5 \\
50.0 \\
16.5 \\
48.0\end{array}$ & $\begin{array}{l}48.9 \\
50.0 \\
16.4 \\
47.4\end{array}$ & 0.0 \\
\hline $\begin{array}{l}\text { Non-least developed countries } \\
\text { Non-least developed countries } \\
\text { Non-least developed countries } \\
\text { Non-least developed countries }\end{array}$ & $\begin{array}{l}\text { Moy } \\
\text { Nbo } \\
\text { Sd } \\
\text { Median }\end{array}$ & $\begin{array}{l}37.8 \\
72.0 \\
16.8 \\
36.1\end{array}$ & $\begin{array}{l}35.0 \\
72.0 \\
15.1 \\
31.5\end{array}$ & $\begin{array}{l}34.8 \\
72.0 \\
12.1 \\
33.5\end{array}$ & 0.0 & $\begin{array}{l}39.4 \\
72.0 \\
16.8 \\
37.6\end{array}$ & $\begin{array}{l}36.1 \\
72.0 \\
15.5 \\
32.6\end{array}$ & $\begin{array}{l}34.0 \\
72.0 \\
14.9 \\
31.2\end{array}$ & $\begin{array}{l}34.6 \\
72.0 \\
13.2 \\
34.1\end{array}$ & $\begin{array}{l}32.8 \\
72.0 \\
11.2 \\
31.8\end{array}$ & 0.0 \\
\hline $\begin{array}{l}\text { SIDS } \\
\text { SIDS } \\
\text { SIDS } \\
\text { SIDS }\end{array}$ & $\begin{array}{l}\text { Moy } \\
\text { Nbo } \\
\text { Sd } \\
\text { Median }\end{array}$ & $\begin{array}{l}50.2 \\
31.0 \\
19.6 \\
51.2\end{array}$ & $\begin{array}{l}46.8 \\
31.0 \\
19.6 \\
42.4\end{array}$ & $\begin{array}{l}44.2 \\
31.0 \\
16.8 \\
41.8\end{array}$ & 0.0 & $\begin{array}{l}52.4 \\
31.0 \\
20.6 \\
52.3\end{array}$ & $\begin{array}{l}48.7 \\
31.0 \\
19.6 \\
44.5\end{array}$ & $\begin{array}{l}46.8 \\
31.0 \\
19.8 \\
43.2\end{array}$ & $\begin{array}{l}47.5 \\
31.0 \\
18.4 \\
45.1\end{array}$ & $\begin{array}{l}43.3 \\
31.0 \\
16.8 \\
43.4\end{array}$ & 0.0 \\
\hline $\begin{array}{l}\text { Non-SIDS } \\
\text { Non-SIDS } \\
\text { Non-SIDS } \\
\text { Non-SIDS }\end{array}$ & $\begin{array}{l}\text { Moy } \\
\text { Nbo } \\
\text { Sd } \\
\text { Median }\end{array}$ & $\begin{array}{l}38.2 \\
91.0 \\
16.5 \\
35.9\end{array}$ & $\begin{array}{l}38.0 \\
91.0 \\
17.2 \\
34.1\end{array}$ & $\begin{array}{l}39.4 \\
91.0 \\
14.5 \\
37.5\end{array}$ & 0.0 & $\begin{array}{l}40.1 \\
91.0 \\
17.4 \\
37.7\end{array}$ & $\begin{array}{l}38.6 \\
91.0 \\
17.1 \\
33.2\end{array}$ & $\begin{array}{l}36.1 \\
91.0 \\
15.1 \\
34.3\end{array}$ & $\begin{array}{l}39.0 \\
91.0 \\
15.4 \\
37.9\end{array}$ & $\begin{array}{l}38.0 \\
91.0 \\
15.2 \\
35.4\end{array}$ & 0.0 \\
\hline $\begin{array}{l}\text { LDCs non-SIDS } \\
\text { LDCs non-SIDS } \\
\text { LDCs non-SIDS } \\
\text { LDCs non-SIDS }\end{array}$ & $\begin{array}{l}\text { Moy } \\
\text { Nbo } \\
\text { Sd } \\
\text { Median }\end{array}$ & $\begin{array}{l}42.2 \\
38.0 \\
17.1 \\
40.1\end{array}$ & $\begin{array}{l}44.7 \\
38.0 \\
18.3 \\
43.2\end{array}$ & $\begin{array}{l}47.3 \\
38.0 \\
14.6 \\
45.4\end{array}$ & 0.0 & $\begin{array}{l}44.3 \\
38.0 \\
19.1 \\
41.4\end{array}$ & $\begin{array}{l}44.8 \\
38.0 \\
17.8 \\
45.9\end{array}$ & $\begin{array}{l}42.1 \\
38.0 \\
14.7 \\
42.6\end{array}$ & $\begin{array}{l}47.3 \\
38.0 \\
15.9 \\
44.3\end{array}$ & $\begin{array}{l}47.0 \\
38.0 \\
15.9 \\
45.5\end{array}$ & 0.0 \\
\hline LDCs/non-LDCs & $\begin{array}{l}\text { Wilcoxonn-z } \\
\text { pvalue-z }\end{array}$ & $\begin{array}{l}-2.4 \\
0.015\end{array}$ & $\begin{array}{l}-3.7 \\
0.000\end{array}$ & $\begin{array}{l}-5.2 \\
0.000\end{array}$ & & $\begin{array}{l}-2.5 \\
0.014\end{array}$ & $\begin{array}{l}-3.5 \\
0.000\end{array}$ & $\begin{array}{l}-3.7 \\
0.000\end{array}$ & $\begin{array}{l}-5.2 \\
0.000\end{array}$ & $\begin{array}{l}-5.6 \\
0.000\end{array}$ & \\
\hline SIDS/non-SIDS & $\begin{array}{l}\text { Wilcoxonn-z } \\
\text { pvalue-z }\end{array}$ & $\begin{array}{l}-3.1 \\
0.002\end{array}$ & $\begin{array}{l}-2.3 \\
0.020\end{array}$ & $\begin{array}{l}-1.5 \\
0.131\end{array}$ & & $\begin{array}{l}-3.0 \\
0.002\end{array}$ & $\begin{array}{l}-2.6 \\
0.010\end{array}$ & $\begin{array}{l}-2.8 \\
0.006\end{array}$ & $\begin{array}{l}-2.5 \\
0.013\end{array}$ & $\begin{array}{l}-1.8 \\
0.078\end{array}$ & \\
\hline SIDS/LDCs non-SIDS & $\begin{array}{l}\text { Wilcoxonn-z } \\
\text { pvalue-z }\end{array}$ & $\begin{array}{l}-1.9 \\
0.057 \\
\end{array}$ & $\begin{array}{l}-0.4 \\
0.664\end{array}$ & $\begin{array}{l}0.9 \\
0.353 \\
\end{array}$ & & $\begin{array}{l}-1.8 \\
0.070 \\
\end{array}$ & $\begin{array}{l}-0.8 \\
0.440\end{array}$ & $\begin{array}{l}-0.9 \\
0.372 \\
\end{array}$ & $\begin{array}{l}-0.1 \\
0.894 \\
\end{array}$ & $\begin{array}{l}1.0 \\
0.341 \\
\end{array}$ & \\
\hline
\end{tabular}

Source: CERDI (2006). 
Appendix Table A3

Exposure index

By groups of countries, by decades, 5-year periods and Wilcoxon tests

\begin{tabular}{|c|c|c|c|c|c|c|c|c|c|c|c|}
\hline Groups & Statistics & $1970-79$ & $1980-89$ & $1990-99$ & $1970-74$ & $1975-79$ & $1980-84$ & $1985-89$ & $1990-94$ & $1995-99$ & $2000-04$ \\
\hline Developing countries & Moy & 52.4 & 48.1 & 46.3 & 53.5 & 51.3 & 48.6 & 47.9 & 46.8 & 45.7 & 45.0 \\
\hline Developing countries & Nbo & 122.0 & 122.0 & 122.0 & 122.0 & 122.0 & 122.0 & 122.0 & 122.0 & 122.0 & 122.0 \\
\hline Developing countries & $S d$ & 16.9 & 17.1 & 17.3 & 16.9 & 17.1 & 17.2 & 17.2 & 17.2 & 17.4 & 17.8 \\
\hline Developing countries & Median & 52.1 & 47.7 & 46.6 & 53.3 & 50.4 & 48.6 & 47.9 & 47.3 & 45.8 & 44.2 \\
\hline Least developed countries & Moy & 59.4 & 55.5 & 53.6 & 60.3 & 58.5 & 56.1 & 55.0 & 54.1 & 53.1 & 51.9 \\
\hline Least developed countries & Nbo & 50.0 & 50.0 & 50.0 & 50.0 & 50.0 & 50.0 & 50.0 & 50.0 & 50.0 & 50.0 \\
\hline Least developed countries & $S d$ & 13.9 & 13.8 & 13.5 & 14.1 & 13.9 & 14.1 & 13.7 & 13.4 & 13.8 & 14.4 \\
\hline Least developed countries & Median & 58.3 & 54.9 & 53.9 & 59.1 & 58.2 & 55.6 & 53.9 & 54.2 & 53.2 & 50.7 \\
\hline Non-least developed countries & Moy & 47.6 & 43.1 & 41.3 & 48.7 & 46.3 & 43.3 & 42.9 & 41.8 & 40.7 & 40.2 \\
\hline Non-least developed countries & Nbo & 72.0 & 72.0 & 72.0 & 72.0 & 72.0 & 72.0 & 72.0 & 72.0 & 72.0 & 72.0 \\
\hline Non-least developed countries & $S d$ & 17.2 & 17.5 & 17.9 & 17.2 & 17.3 & 17.3 & 17.6 & 17.8 & 17.9 & 18.3 \\
\hline Non-least developed countries & Median & 44.7 & 40.4 & 38.0 & 46.1 & 43.1 & 41.1 & 40.4 & 39.0 & 37.2 & 36.7 \\
\hline SIDS & Moy & 68.6 & 64.7 & 63.6 & 69.7 & 67.5 & 64.9 & 64.7 & 63.7 & 63.3 & 63.9 \\
\hline SIDS & Nbo & 31.0 & 31.0 & 31.0 & 31.0 & 31.0 & 31.0 & 31.0 & 31.0 & 31.0 & 31.0 \\
\hline SIDS & $S d$ & 12.5 & 12.7 & 12.2 & 12.5 & 12.6 & 13.0 & 12.4 & 12.3 & 12.4 & 12.3 \\
\hline SIDS & Median & 70.9 & 65.8 & 66.4 & 72.9 & 70.9 & 67.2 & 65.9 & 66.5 & 66.2 & 66.2 \\
\hline Non-SIDS & Moy & 46.9 & 42.5 & 40.4 & 47.9 & 45.8 & 43.0 & 42.1 & 41.1 & 39.7 & 38.6 \\
\hline Non-SIDS & Nbo & 91.0 & 91.0 & 91.0 & 91.0 & 91.0 & 91.0 & 91.0 & 91.0 & 91.0 & 91.0 \\
\hline Non-SIDS & $S d$ & 14.6 & 14.7 & 14.6 & 14.5 & 14.7 & 14.8 & 14.6 & 14.7 & 14.6 & 14.4 \\
\hline Non-SIDS & Median & 45.4 & 44.0 & 41.3 & 46.9 & 44.5 & 43.8 & 45.0 & 41.9 & 39.8 & 37.7 \\
\hline LDCs non-SIDS & Moy & 54.8 & 50.8 & 48.8 & 55.6 & 54.0 & 51.3 & 50.3 & 49.6 & 48.1 & 46.5 \\
\hline LDCs non-SIDS & Nbo & 38.0 & 38.0 & 38.0 & 38.0 & 38.0 & 38.0 & 38.0 & 38.0 & 38.0 & 38.0 \\
\hline LDCs non-SIDS & $S d$ & 11.4 & 11.0 & 10.7 & 11.5 & 11.4 & 11.2 & 10.9 & 10.8 & 10.7 & 10.8 \\
\hline LDCs non-SIDS & Median & 56.0 & 51.2 & 48.6 & 56.6 & 54.6 & 51.7 & 51.6 & 50.6 & 47.2 & 46.5 \\
\hline LDCs/non-LDCs & $\begin{array}{l}\text { Wilcoxonn-z } \\
\text { pvalue-z }\end{array}$ & $\begin{array}{l}-3.7 \\
0.000\end{array}$ & $\begin{array}{l}-3.9 \\
0.000\end{array}$ & $\begin{array}{l}-3.8 \\
0.000\end{array}$ & $\begin{array}{l}-3.7 \\
0.000\end{array}$ & $\begin{array}{l}-3.8 \\
0.000\end{array}$ & $\begin{array}{l}-3.9 \\
0.000\end{array}$ & $\begin{array}{l}-3.8 \\
0.000\end{array}$ & $\begin{array}{l}-3.8 \\
0.000\end{array}$ & $\begin{array}{l}-3.9 \\
0.000\end{array}$ & $\begin{array}{l}-3.7 \\
0.000\end{array}$ \\
\hline SIDS/non-SIDS & Wilcoxonn-z & & & & & & & & & & \\
\hline & pvalue-z & 0.000 & 0.000 & 0.000 & 0.000 & 0.000 & 0.000 & 0.000 & 0.000 & 0.000 & 0.000 \\
\hline SIDS/LDCs non-SIDS & Wilcoxonn-z & -4.3 & -4.5 & -4.7 & -4.3 & -4.3 & -4.4 & -4.6 & -4.6 & -4.7 & -5.0 \\
\hline & pvalue-z & 0.000 & 0.000 & 0.000 & 0.000 & 0.000 & 0.000 & 0.000 & 0.000 & 0.000 & 0.000 \\
\hline
\end{tabular}

Source: CERDI (2006). 
Appendix Table A4

Homeless

By groups of countries, by decades, 5-year periods and Wilcoxon tests

\begin{tabular}{|c|c|c|c|c|c|c|c|c|c|c|c|}
\hline Groups & Statistics & $1970-79$ & $1980-89$ & $1990-99$ & $1970-74$ & $1975-79$ & $1980-84$ & $1985-89$ & $1990-94$ & $1995-99$ & $2000-04$ \\
\hline Developing countries & Moy & 41.5 & 41.5 & 42.9 & & 41.5 & 44.1 & 41.5 & 45.1 & 42.9 & \\
\hline Developing countries & Nbo & 122.0 & 122.0 & 122.0 & 0.0 & 122.0 & 122.0 & 122.0 & 122.0 & 122.0 & 0.0 \\
\hline Developing countries & $S d$ & 26.9 & 29.5 & 26.9 & & 26.9 & 27.3 & 29.5 & 27.2 & 26.9 & \\
\hline Developing countries & Median & 41.1 & 40.0 & 44.3 & & 41.1 & 43.3 & 40.0 & 43.7 & 44.3 & \\
\hline Least developed countries & Moy & 47.9 & 51.1 & 50.1 & & 47.9 & 51.5 & 51.1 & 53.6 & 50.1 & \\
\hline Least developed countries & Nbo & 50.0 & 50.0 & 50.0 & 0.0 & 50.0 & 50.0 & 50.0 & 50.0 & 50.0 & 0.0 \\
\hline Least developed countries & $S d$ & 24.6 & 28.2 & 26.3 & & 24.6 & 24.6 & 28.2 & 25.1 & 26.3 & \\
\hline Least developed countries & Median & 46.6 & 48.5 & 52.9 & & 46.6 & 48.8 & 48.5 & 51.5 & 52.9 & \\
\hline Non-least developed countries & Moy & 37.1 & 34.9 & 37.9 & & 37.1 & 39.0 & 34.9 & 39.2 & 37.9 & \\
\hline Non-least developed countries & Nbo & 72.0 & 72.0 & 72.0 & 0.0 & 72.0 & 72.0 & 72.0 & 72.0 & 72.0 & 0.0 \\
\hline Non-least developed countries & $S d$ & 27.8 & 28.7 & 26.3 & & 27.8 & 28.0 & 28.7 & 27.2 & 26.3 & \\
\hline Non-least developed countries & Median & 36.7 & 29.6 & 37.7 & & 36.7 & 36.8 & 29.6 & 41.0 & 37.7 & \\
\hline SIDS & Moy & 57.0 & 56.0 & 50.8 & & 57.0 & 58.7 & 56.0 & 56.7 & 50.8 & \\
\hline SIDS & Nbo & 31.0 & 31.0 & 31.0 & 0.0 & 31.0 & 31.0 & 31.0 & 31.0 & 31.0 & 0.0 \\
\hline SIDS & $S d$ & 28.9 & 32.0 & 32.0 & & 28.9 & 29.8 & 32.0 & 31.2 & 32.0 & \\
\hline SIDS & Median & 61.1 & 59.8 & 59.8 & & 61.1 & 64.0 & 59.8 & 61.1 & 59.8 & \\
\hline Non-SIDS & Moy & 36.3 & 36.6 & 40.2 & & 36.3 & 39.2 & 36.6 & 41.1 & 40.2 & \\
\hline Non-SIDS & Nbo & 91.0 & 91.0 & 91.0 & 0.0 & 91.0 & 91.0 & 91.0 & 91.0 & 91.0 & 0.0 \\
\hline Non-SIDS & $S d$ & 24.2 & 27.0 & 24.5 & & 24.2 & 24.6 & 27.0 & 24.6 & 24.5 & \\
\hline Non-SIDS & Median & 37.0 & 30.5 & 41.5 & & 37.0 & 38.3 & 30.5 & 40.5 & 41.5 & \\
\hline LDCs non-SIDS & Moy & 41.1 & 44.6 & 46.0 & & 41.1 & 45.4 & 44.6 & 47.8 & 46.0 & \\
\hline LDCs non-SIDS & Nbo & 38.0 & 38.0 & 38.0 & 0.0 & 38.0 & 38.0 & 38.0 & 38.0 & 38.0 & 0.0 \\
\hline LDCs non-SIDS & $S d$ & 20.7 & 26.2 & 22.3 & & 20.7 & 21.6 & 26.2 & 22.9 & 22.3 & \\
\hline LDCs non-SIDS & Median & 41.1 & 45.6 & 47.0 & & 41.1 & 45.0 & 45.6 & 42.7 & 47.0 & \\
\hline LDCs/non-LDCs & $\begin{array}{l}\text { Wilcoxonn-z } \\
\text { pvalue-z }\end{array}$ & $\begin{array}{l}-2.0 \\
0.043\end{array}$ & $\begin{array}{l}-3.0 \\
0.002\end{array}$ & $\begin{array}{l}-2.3 \\
0.021\end{array}$ & & $\begin{array}{l}-2.0 \\
0.043\end{array}$ & $\begin{array}{l}-2.3 \\
0.020\end{array}$ & $\begin{array}{l}-3.0 \\
0.002\end{array}$ & $\begin{array}{l}-2.7 \\
0.008\end{array}$ & $\begin{array}{l}-2.3 \\
0.021\end{array}$ & \\
\hline SIDS/non-SIDS & $\begin{array}{l}\text { Wilcoxonn-z } \\
\text { pvalue-z }\end{array}$ & $\begin{array}{l}-3.7 \\
0.000\end{array}$ & $\begin{array}{l}-3.0 \\
0.003\end{array}$ & $\begin{array}{l}-1.9 \\
0.060\end{array}$ & & $\begin{array}{l}-3.7 \\
0.000\end{array}$ & $\begin{array}{l}-3.5 \\
0.001\end{array}$ & $\begin{array}{l}-3.0 \\
0.003\end{array}$ & $\begin{array}{l}-2.8 \\
0.005\end{array}$ & $\begin{array}{l}-1.9 \\
0.060\end{array}$ & \\
\hline SIDS/LDCs non-SIDS & $\begin{array}{l}\text { Wilcoxonn-z } \\
\text { pvalue-z }\end{array}$ & $\begin{array}{l}-2.9 \\
0.004 \\
\end{array}$ & $\begin{array}{l}-1.7 \\
0.088 \\
\end{array}$ & $\begin{array}{l}-1.0 \\
0.302 \\
\end{array}$ & & $\begin{array}{l}-2.9 \\
0.004 \\
\end{array}$ & $\begin{array}{l}-2.5 \\
0.012 \\
\end{array}$ & $\begin{array}{l}-1.7 \\
0.088 \\
\end{array}$ & $\begin{array}{l}-1.7 \\
0.084 \\
\end{array}$ & $\begin{array}{l}-1.0 \\
0.302 \\
\end{array}$ & \\
\hline
\end{tabular}

Source: CERDI (2006). 
Appendix Table A5

Agricultural instability

By groups of countries, by decades, 5-year periods and Wilcoxon tests

\begin{tabular}{|c|c|c|c|c|c|c|c|c|c|c|c|}
\hline Groups & Statistics & $1970-79$ & $1980-89$ & $1990-99$ & $1970-74$ & $1975-79$ & $1980-84$ & $1985-89$ & $1990-94$ & 1995-99 & $2000-04$ \\
\hline Developing countries & Moy & 29.9 & 30.9 & 46.1 & 28.1 & 29.9 & 31.5 & 30.9 & 45.3 & 46.1 & 45.5 \\
\hline Developing countries & Nbo & 122.0 & 122.0 & 122.0 & 122.0 & 122.0 & 122.0 & 122.0 & 122.0 & 122.0 & 122.0 \\
\hline Developing countries & $S d$ & 23.5 & 22.1 & 25.0 & 23.1 & 23.5 & 22.2 & 22.1 & 25.0 & 25.0 & 25.8 \\
\hline Developing countries & Median & 23.4 & 22.9 & 39.4 & 21.9 & 23.4 & 25.1 & 22.9 & 40.1 & 39.4 & 38.3 \\
\hline Least developed countries & Moy & 28.5 & 32.4 & 48.4 & 26.1 & 28.5 & 32.1 & 32.4 & 48.8 & 48.4 & 46.1 \\
\hline Least developed countries & Nbo & 50.0 & 50.0 & 50.0 & 50.0 & 50.0 & 50.0 & 50.0 & 50.0 & 50.0 & 50.0 \\
\hline Least developed countries & $S d$ & 22.3 & 24.5 & 26.7 & 20.4 & 22.3 & 23.4 & 24.5 & 27.1 & 26.7 & 27.5 \\
\hline Least developed countries & Median & 23.0 & 24.2 & 42.6 & 22.6 & 23.0 & 25.1 & 24.2 & 47.1 & 42.6 & 40.4 \\
\hline Non-least developed countries & Moy & 30.8 & 29.8 & 44.5 & 29.4 & 30.8 & 31.1 & 29.8 & 42.8 & 44.5 & 45.2 \\
\hline Non-least developed countries & Nbo & 72.0 & 72.0 & 72.0 & 72.0 & 72.0 & 72.0 & 72.0 & 72.0 & 72.0 & 72.0 \\
\hline Non-least developed countries & Sd & 24.4 & 20.4 & 23.8 & 24.8 & 24.4 & 21.5 & 20.4 & 23.3 & 23.8 & 24.7 \\
\hline Non-least developed countries & Median & 23.7 & 22.9 & 38.6 & 21.4 & 23.7 & 25.0 & 22.9 & 38.1 & 38.6 & 37.9 \\
\hline SIDS & Moy & 35.7 & 37.7 & 47.8 & 34.5 & 35.7 & 36.3 & 37.7 & 49.4 & 47.8 & 45.5 \\
\hline SIDS & Nbo & 31.0 & 31.0 & 31.0 & 31.0 & 31.0 & 31.0 & 31.0 & 31.0 & 31.0 & 31.0 \\
\hline SIDS & $S d$ & 24.1 & 23.2 & 27.3 & 23.7 & 24.1 & 19.5 & 23.2 & 26.7 & 27.3 & 28.1 \\
\hline SIDS & Median & 30.9 & 35.5 & 38.1 & 32.1 & 30.9 & 33.3 & 35.5 & 42.8 & 38.1 & 38.3 \\
\hline Non-SIDS & Moy & 27.9 & 28.5 & 45.5 & 25.9 & 27.9 & 29.9 & 28.5 & 43.8 & 45.5 & 45.5 \\
\hline Non-SIDS & Nbo & 91.0 & 91.0 & 91.0 & 91.0 & 91.0 & 91.0 & 91.0 & 91.0 & 91.0 & 91.0 \\
\hline Non-SIDS & $S d$ & 23.1 & 21.3 & 24.3 & 22.6 & 23.1 & 22.9 & 21.3 & 24.4 & 24.3 & 25.2 \\
\hline Non-SIDS & Median & 20.4 & 19.9 & 39.7 & 17.5 & 20.4 & 22.9 & 19.9 & 39.0 & 39.7 & 43.4 \\
\hline LDCs non-SIDS & Moy & 28.3 & 30.8 & 49.1 & 25.4 & 28.3 & 31.1 & 30.8 & 48.2 & 49.1 & 47.6 \\
\hline LDCs non-SIDS & Nbo & 38.0 & 38.0 & 38.0 & 38.0 & 38.0 & 38.0 & 38.0 & 38.0 & 38.0 & 38.0 \\
\hline LDCs non-SIDS & $S d$ & 23.3 & 23.9 & 27.2 & 20.7 & 23.3 & 23.7 & 23.9 & 26.8 & 27.2 & 28.4 \\
\hline LDCs non-SIDS & Median & 21.4 & 22.4 & 43.0 & 21.1 & 21.4 & 24.1 & 22.4 & 45.3 & 43.0 & 45.2 \\
\hline \multirow[t]{2}{*}{ LDCs/non-LDCs } & Wilcoxonn-z & 0.2 & -0.4 & -0.8 & 0.4 & 0.2 & -0.1 & -0.4 & -1.2 & -0.8 & 0.0 \\
\hline & pvalue-z & 0.841 & 0.723 & 0.447 & 0.700 & 0.841 & 0.934 & 0.723 & 0.244 & 0.447 & 1.000 \\
\hline \multirow[t]{2}{*}{ SIDS/non-SIDS } & Wilcoxonn-z & -2.3 & -2.2 & -0.3 & -2.4 & -2.3 & -2.1 & -2.2 & -1.1 & -0.3 & 0.1 \\
\hline & pvalue-z & 0.023 & 0.026 & 0.775 & 0.015 & 0.023 & 0.033 & 0.026 & 0.268 & 0.775 & 0.881 \\
\hline \multirow[t]{2}{*}{ SIDS/LDCs non-SIDS } & Wilcoxonn-z & -1.8 & -1.6 & 0.3 & -2.0 & -1.8 & -1.7 & -1.6 & -0.2 & 0.3 & 0.4 \\
\hline & pvalue-z & 0.067 & 0.117 & 0.754 & 0.041 & 0.067 & 0.096 & 0.117 & 0.852 & 0.754 & 0.690 \\
\hline
\end{tabular}

Source: CERDI (2006). 
Appendix Table A6

Instability of exports, ex post

By groups of countries, by decades, 5-year periods and Wilcoxon tests

\begin{tabular}{|c|c|c|c|c|c|c|c|c|c|c|c|}
\hline Groups & Statistics & $1970-79$ & $1980-89$ & $1990-99$ & $1970-74$ & $1975-79$ & $1980-84$ & $1985-89$ & $1990-94$ & $1995-99$ & $2000-04$ \\
\hline $\begin{array}{l}\text { Developing countries } \\
\text { Developing countries } \\
\text { Developing countries } \\
\text { Developing countries }\end{array}$ & $\begin{array}{l}\text { Moy } \\
\text { Nbo } \\
\text { Sd } \\
\text { Median }\end{array}$ & $\begin{array}{r}46.7 \\
122.0 \\
25.6 \\
41.4\end{array}$ & $\begin{array}{r}44.3 \\
122.0 \\
25.0 \\
38.4\end{array}$ & $\begin{array}{r}36.7 \\
122.0 \\
24.9 \\
30.2\end{array}$ & $\begin{array}{r}45.3 \\
122.0 \\
26.9 \\
37.3\end{array}$ & $\begin{array}{r}50.8 \\
122.0 \\
27.9 \\
43.4\end{array}$ & $\begin{array}{r}44.5 \\
122.0 \\
26.9 \\
37.2\end{array}$ & $\begin{array}{r}41.5 \\
122.0 \\
23.8 \\
37.8\end{array}$ & $\begin{array}{r}37.1 \\
122.0 \\
25.8 \\
27.4\end{array}$ & $\begin{array}{r}34.2 \\
122.0 \\
26.0 \\
26.6\end{array}$ & $\begin{array}{r}33.8 \\
122.0 \\
26.2 \\
27.7\end{array}$ \\
\hline $\begin{array}{l}\text { Least developed countries } \\
\text { Least developed countries } \\
\text { Least developed countries } \\
\text { Least developed countries }\end{array}$ & $\begin{array}{l}\text { Moy } \\
\text { Nbo } \\
\text { Sd } \\
\text { Median }\end{array}$ & $\begin{array}{l}54.2 \\
50.0 \\
25.3 \\
51.9\end{array}$ & $\begin{array}{l}53.9 \\
50.0 \\
26.5 \\
50.3\end{array}$ & $\begin{array}{l}48.8 \\
50.0 \\
27.6 \\
39.4\end{array}$ & $\begin{array}{l}49.4 \\
50.0 \\
24.2 \\
42.8\end{array}$ & $\begin{array}{l}59.3 \\
50.0 \\
29.8 \\
58.4\end{array}$ & $\begin{array}{l}55.1 \\
50.0 \\
27.8 \\
50.4\end{array}$ & $\begin{array}{l}50.0 \\
50.0 \\
25.5 \\
44.3\end{array}$ & $\begin{array}{l}49.9 \\
50.0 \\
27.6 \\
44.2\end{array}$ & $\begin{array}{l}48.4 \\
50.0 \\
29.3 \\
41.0\end{array}$ & $\begin{array}{l}45.4 \\
50.0 \\
29.3 \\
35.3\end{array}$ \\
\hline $\begin{array}{l}\text { Non-least developed countries } \\
\text { Non-least developed countries } \\
\text { Non-least developed countries } \\
\text { Non-least developed countries }\end{array}$ & $\begin{array}{l}\text { Moy } \\
\text { Nbo } \\
\text { Sd } \\
\text { Median }\end{array}$ & $\begin{array}{l}41.5 \\
72.0 \\
24.6 \\
35.8\end{array}$ & $\begin{array}{l}37.7 \\
72.0 \\
21.7 \\
32.9\end{array}$ & $\begin{array}{l}28.4 \\
72.0 \\
18.9 \\
21.0\end{array}$ & $\begin{array}{l}42.4 \\
72.0 \\
28.4 \\
33.6\end{array}$ & $\begin{array}{l}44.9 \\
72.0 \\
25.1 \\
38.3\end{array}$ & $\begin{array}{l}37.1 \\
72.0 \\
23.8 \\
30.9\end{array}$ & $\begin{array}{l}35.6 \\
72.0 \\
20.7 \\
31.9\end{array}$ & $\begin{array}{l}28.2 \\
72.0 \\
20.3 \\
19.5\end{array}$ & $\begin{array}{l}24.4 \\
72.0 \\
17.9 \\
19.4\end{array}$ & $\begin{array}{l}25.7 \\
72.0 \\
20.4 \\
20.3\end{array}$ \\
\hline $\begin{array}{l}\text { SIDS } \\
\text { SIDS } \\
\text { SIDS } \\
\text { SIDS }\end{array}$ & $\begin{array}{l}\text { Moy } \\
\text { Nbo } \\
\text { Sd } \\
\text { Median }\end{array}$ & $\begin{array}{l}54.0 \\
31.0 \\
24.9 \\
54.9\end{array}$ & $\begin{array}{l}46.7 \\
31.0 \\
24.8 \\
39.6\end{array}$ & $\begin{array}{l}39.0 \\
31.0 \\
27.6 \\
30.1\end{array}$ & $\begin{array}{l}49.6 \\
31.0 \\
25.9 \\
47.0\end{array}$ & $\begin{array}{l}58.5 \\
31.0 \\
27.9 \\
59.0\end{array}$ & $\begin{array}{l}49.9 \\
31.0 \\
27.0 \\
41.9\end{array}$ & $\begin{array}{l}46.8 \\
31.0 \\
26.8 \\
38.9\end{array}$ & $\begin{array}{l}41.8 \\
31.0 \\
29.0 \\
37.3\end{array}$ & $\begin{array}{l}37.4 \\
31.0 \\
28.2 \\
34.6\end{array}$ & $\begin{array}{l}34.8 \\
31.0 \\
28.2 \\
28.7\end{array}$ \\
\hline $\begin{array}{l}\text { Non-SIDS } \\
\text { Non-SIDS } \\
\text { Non-SIDS } \\
\text { Non-SIDS }\end{array}$ & $\begin{array}{l}\text { Moy } \\
\text { Nbo } \\
\text { Sd } \\
\text { Median }\end{array}$ & $\begin{array}{l}44.3 \\
91.0 \\
25.5 \\
37.5\end{array}$ & $\begin{array}{l}43.5 \\
91.0 \\
25.1 \\
36.6\end{array}$ & $\begin{array}{l}36.0 \\
91.0 \\
24.0 \\
30.3\end{array}$ & $\begin{array}{l}43.8 \\
91.0 \\
27.2 \\
35.9\end{array}$ & $\begin{array}{l}48.2 \\
91.0 \\
27.6 \\
38.8\end{array}$ & $\begin{array}{l}42.6 \\
91.0 \\
26.8 \\
33.6\end{array}$ & $\begin{array}{l}39.7 \\
91.0 \\
22.6 \\
36.4\end{array}$ & $\begin{array}{l}35.5 \\
91.0 \\
24.5 \\
27.1\end{array}$ & $\begin{array}{l}33.2 \\
91.0 \\
25.3 \\
26.5\end{array}$ & $\begin{array}{l}33.5 \\
91.0 \\
25.6 \\
26.4\end{array}$ \\
\hline $\begin{array}{l}\text { LDCs non-SIDS } \\
\text { LDCs non-SIDS } \\
\text { LDCs non-SIDS } \\
\text { LDCs non-SIDS }\end{array}$ & $\begin{array}{l}\text { Moy } \\
\text { Nbo } \\
\text { Sd } \\
\text { Median }\end{array}$ & $\begin{array}{l}49.7 \\
38.0 \\
24.4 \\
48.5\end{array}$ & $\begin{array}{l}51.7 \\
38.0 \\
26.0 \\
48.7\end{array}$ & $\begin{array}{l}47.0 \\
38.0 \\
25.9 \\
36.8\end{array}$ & $\begin{array}{l}47.4 \\
38.0 \\
24.3 \\
40.3\end{array}$ & $\begin{array}{l}53.9 \\
38.0 \\
29.6 \\
49.8\end{array}$ & $\begin{array}{l}51.3 \\
38.0 \\
27.1 \\
45.6\end{array}$ & $\begin{array}{l}46.4 \\
38.0 \\
23.6 \\
42.2\end{array}$ & $\begin{array}{l}46.7 \\
38.0 \\
26.7 \\
37.6\end{array}$ & $\begin{array}{l}46.5 \\
38.0 \\
28.7 \\
38.2\end{array}$ & $\begin{array}{l}43.5 \\
38.0 \\
28.6 \\
33.6\end{array}$ \\
\hline LDCs/non-LDCs & $\begin{array}{l}\text { Wilcoxonn-z } \\
\text { pvalue-z }\end{array}$ & $\begin{array}{l}-2.9 \\
0.003\end{array}$ & $\begin{array}{l}-3.3 \\
0.001\end{array}$ & $\begin{array}{l}-4.4 \\
0.000\end{array}$ & $\begin{array}{l}-2.0 \\
0.047\end{array}$ & $\begin{array}{l}-2.5 \\
0.011\end{array}$ & $\begin{array}{l}-3.7 \\
0.000\end{array}$ & $\begin{array}{l}-3.2 \\
0.002\end{array}$ & $\begin{array}{l}-4.7 \\
0.000\end{array}$ & $\begin{array}{l}-5.0 \\
0.000\end{array}$ & $\begin{array}{l}-4.1 \\
0.000\end{array}$ \\
\hline SIDS/non-SIDS & $\begin{array}{l}\text { Wilcoxonn-z } \\
\text { pvalue-z }\end{array}$ & $\begin{array}{l}-2.1 \\
0.036\end{array}$ & $\begin{array}{l}-0.8 \\
0.402\end{array}$ & $\begin{array}{l}-0.2 \\
0.830\end{array}$ & $\begin{array}{l}-1.2 \\
0.218\end{array}$ & $\begin{array}{l}-1.9 \\
0.057\end{array}$ & $\begin{array}{l}-1.6 \\
0.114\end{array}$ & $\begin{array}{l}-1.2 \\
0.230\end{array}$ & $\begin{array}{l}-0.8 \\
0.405\end{array}$ & $\begin{array}{l}-0.6 \\
0.554\end{array}$ & $\begin{array}{l}0.1 \\
0.955\end{array}$ \\
\hline SIDS/LDCs non-SIDS & $\begin{array}{l}\text { Wilcoxonn-z } \\
\text { pvalue-z }\end{array}$ & $\begin{array}{l}-0.8 \\
0.408\end{array}$ & $\begin{array}{l}0.7 \\
0.476\end{array}$ & $\begin{array}{l}1.6 \\
0.106\end{array}$ & $\begin{array}{l}-0.3 \\
0.772 \\
\end{array}$ & $\begin{array}{l}-0.8 \\
0.415\end{array}$ & $\begin{array}{l}0.1 \\
0.894\end{array}$ & $\begin{array}{l}0.1 \\
0.904\end{array}$ & $\begin{array}{l}1.0 \\
0.299\end{array}$ & $\begin{array}{l}1.5 \\
0.125\end{array}$ & $\begin{array}{l}1.5 \\
0.144 \\
\end{array}$ \\
\hline
\end{tabular}

Source: CERDI (2006). 
Appendix Table A7

Population

By groups of countries, by decades, 5-year periods and Wilcoxon tests

\begin{tabular}{|c|c|c|c|c|c|c|c|c|c|c|c|}
\hline Groups & Statistics & $1970-79$ & $1980-89$ & $1990-99$ & $1970-74$ & $1975-79$ & $1980-84$ & $1985-89$ & $1990-94$ & 1995-99 & $2000-04$ \\
\hline Developing countries & Moy & 52.6 & 49.2 & 46.1 & 53.4 & 51.8 & 50.1 & 48.4 & 46.8 & 45.4 & 44.1 \\
\hline Developing countries & Nbo & 122.0 & 122.0 & 122.0 & 122.0 & 122.0 & 122.0 & 122.0 & 122.0 & 122.0 & 122.0 \\
\hline Developing countries & $S d$ & 28.4 & 29.0 & 29.5 & 28.2 & 28.6 & 28.9 & 29.2 & 29.4 & 29.6 & 29.7 \\
\hline Developing countries & Median & 48.3 & 44.3 & 41.5 & 49.6 & 47.5 & 45.3 & 43.4 & 42.1 & 40.8 & 38.2 \\
\hline Least developed countries & Moy & 57.4 & 53.8 & 50.2 & 58.3 & 56.6 & 54.8 & 52.9 & 51.1 & 49.4 & 47.6 \\
\hline Least developed countries & Nbo & 50.0 & 50.0 & 50.0 & 50.0 & 50.0 & 50.0 & 50.0 & 50.0 & 50.0 & 50.0 \\
\hline Least developed countries & $S d$ & 25.8 & 26.4 & 27.0 & 25.6 & 26.1 & 26.3 & 26.5 & 26.8 & 27.1 & 27.3 \\
\hline Least developed countries & Median & 49.8 & 46.1 & 42.7 & 51.0 & 49.2 & 47.3 & 45.0 & 43.0 & 42.2 & 39.7 \\
\hline Non-least developed countries & Moy & 49.2 & 46.0 & 43.2 & 50.0 & 48.4 & 46.8 & 45.3 & 43.9 & 42.6 & 41.6 \\
\hline Non-least developed countries & Nbo & 72.0 & 72.0 & 72.0 & 72.0 & 72.0 & 72.0 & 72.0 & 72.0 & 72.0 & 72.0 \\
\hline Non-least developed countries & $S d$ & 29.8 & 30.5 & 31.0 & 29.6 & 30.0 & 30.3 & 30.6 & 30.9 & 31.1 & 31.2 \\
\hline Non-least developed countries & Median & 45.1 & 41.4 & 38.4 & 46.1 & 44.2 & 42.3 & 40.5 & 39.0 & 37.8 & 36.7 \\
\hline SIDS & Moy & 85.5 & 84.1 & 82.5 & 85.9 & 85.2 & 84.5 & 83.7 & 82.9 & 82.1 & 81.4 \\
\hline SIDS & Nbo & 31.0 & 31.0 & 31.0 & 31.0 & 31.0 & 31.0 & 31.0 & 31.0 & 31.0 & 31.0 \\
\hline SIDS & $S d$ & 19.2 & 20.1 & 20.7 & 18.9 & 19.4 & 19.9 & 20.3 & 20.6 & 20.8 & 21.1 \\
\hline SIDS & Median & 96.4 & 92.0 & 91.5 & 97.8 & 95.1 & 92.4 & 91.9 & 91.6 & 91.1 & 89.1 \\
\hline Non-SIDS & Moy & 41.3 & 37.3 & 33.7 & 42.3 & 40.4 & 38.4 & 36.4 & 34.5 & 32.9 & 31.4 \\
\hline Non-SIDS & Nbo & 91.0 & 91.0 & 91.0 & 91.0 & 91.0 & 91.0 & 91.0 & 91.0 & 91.0 & 91.0 \\
\hline Non-SIDS & $S d$ & 21.5 & 20.9 & 20.4 & 21.6 & 21.4 & 21.1 & 20.7 & 20.5 & 20.2 & 19.9 \\
\hline Non-SIDS & Median & 42.0 & 37.5 & 33.6 & 43.8 & 41.3 & 39.0 & 36.1 & 34.3 & 32.7 & 31.6 \\
\hline LDCs non-SIDS & Moy & 47.2 & 43.1 & 39.2 & 48.2 & 46.3 & 44.2 & 42.1 & 40.1 & 38.3 & 36.3 \\
\hline LDCs non-SIDS & Nbo & 38.0 & 38.0 & 38.0 & 38.0 & 38.0 & 38.0 & 38.0 & 38.0 & 38.0 & 38.0 \\
\hline LDCs non-SIDS & $S d$ & 19.0 & 18.7 & 18.6 & 19.0 & 19.1 & 18.8 & 18.6 & 18.6 & 18.7 & 18.5 \\
\hline LDCs non-SIDS & Median & 45.7 & 41.1 & 36.7 & 47.0 & 44.6 & 42.0 & 39.9 & 37.7 & 35.7 & 34.0 \\
\hline LDCs/non-LDCs & $\begin{array}{l}\text { Wilcoxonn-z } \\
\text { pvalue-z }\end{array}$ & $\begin{array}{l}-1.5 \\
0.132\end{array}$ & $\begin{array}{l}-1.5 \\
0.130\end{array}$ & $\begin{array}{l}-1.4 \\
0.158\end{array}$ & $\begin{array}{l}-1.5 \\
0.136\end{array}$ & $\begin{array}{l}-1.5 \\
0.130\end{array}$ & $\begin{array}{l}-1.5 \\
0.127\end{array}$ & $\begin{array}{l}-1.5 \\
0.123\end{array}$ & $\begin{array}{l}-1.5 \\
0.147\end{array}$ & $\begin{array}{l}-1.4 \\
0.167\end{array}$ & $\begin{array}{l}-1.2 \\
0.217\end{array}$ \\
\hline SIDS/non-SIDS & $\begin{array}{l}\text { Wilcoxonn-z } \\
\text { pvalue-z }\end{array}$ & $\begin{array}{l}-7.1 \\
0.000\end{array}$ & $\begin{array}{l}-7.2 \\
0.000\end{array}$ & $\begin{array}{l}-7.3 \\
0.000\end{array}$ & $\begin{array}{l}-7.1 \\
0.000\end{array}$ & $\begin{array}{l}-7.1 \\
0.000\end{array}$ & $\begin{array}{l}-7.1 \\
0.000\end{array}$ & $\begin{array}{l}-7.2 \\
0.000\end{array}$ & $\begin{array}{l}-7.3 \\
0.000\end{array}$ & $\begin{array}{l}-7.3 \\
0.000\end{array}$ & $\begin{array}{l}-7.4 \\
0.000\end{array}$ \\
\hline SIDS/LDCs non-SIDS & Wilcoxonn-z & -5.8 & -5.9 & -6.0 & -5.8 & -5.9 & -5.9 & -5.9 & -5.9 & -6.0 & -6.1 \\
\hline
\end{tabular}

Source: CERDI (2006). 
Appendix Table A8

Remoteness, ex post

By groups of countries, by decades, 5-year periods and Wilcoxon tests

\begin{tabular}{|c|c|c|c|c|c|c|c|c|c|c|c|}
\hline Groups & Statistics & $1970-79$ & $1980-89$ & 1990-99 & $1970-74$ & $1975-79$ & $1980-84$ & $1985-89$ & $1990-94$ & 1995-99 & $2000-04$ \\
\hline Developing countries & Moy & 58.3 & 54.7 & 54.3 & 59.3 & 57.1 & 54.9 & 54.9 & 54.3 & 54.1 & 54.9 \\
\hline Developing countries & Nbo & 122.0 & 122.0 & 122.0 & 122.0 & 122.0 & 122.0 & 122.0 & 122.0 & 122.0 & 122.0 \\
\hline Developing countries & $S d$ & 19.8 & 19.5 & 18.9 & 19.9 & 20.2 & 19.8 & 19.1 & 19.1 & 19.0 & 18.8 \\
\hline Developing countries & Median & 58.1 & 51.8 & 50.6 & 58.6 & 56.3 & 52.2 & 51.3 & 50.9 & 51.0 & 52.1 \\
\hline Least developed countries & Moy & 65.8 & 61.8 & 60.9 & 66.9 & 64.7 & 62.4 & 61.8 & 61.1 & 60.9 & 60.4 \\
\hline Least developed countries & $\mathrm{Nbo}$ & 50.0 & 50.0 & 50.0 & 50.0 & 50.0 & 50.0 & 50.0 & 50.0 & 50.0 & 50.0 \\
\hline Least developed countries & $S d$ & 15.0 & 15.3 & 14.6 & 15.1 & 15.4 & 15.6 & 15.1 & 14.8 & 14.5 & 14.4 \\
\hline Least developed countries & Median & 65.6 & 60.2 & 58.8 & 66.3 & 64.1 & 61.2 & 59.7 & 58.3 & 59.1 & 59.2 \\
\hline Non-least developed countries & Moy & 53.2 & 49.8 & 49.7 & 54.1 & 51.8 & 49.7 & 50.2 & 49.6 & 49.4 & 51.1 \\
\hline Non-least developed countries & Nbo & 72.0 & 72.0 & 72.0 & 72.0 & 72.0 & 72.0 & 72.0 & 72.0 & 72.0 & 72.0 \\
\hline Non-least developed countries & $\mathrm{Sd}$ & 21.2 & 20.6 & 20.3 & 21.1 & 21.5 & 20.9 & 20.2 & 20.3 & 20.4 & 20.6 \\
\hline Non-least developed countries & Median & 52.4 & 48.0 & 48.7 & 53.4 & 51.4 & 47.9 & 48.9 & 48.9 & 48.0 & 51.5 \\
\hline SIDS & Moy & 56.1 & 52.3 & 52.4 & 57.9 & 54.2 & 52.2 & 53.3 & 52.0 & 52.3 & 56.1 \\
\hline SIDS & Nbo & 31.0 & 31.0 & 31.0 & 31.0 & 31.0 & 31.0 & 31.0 & 31.0 & 31.0 & 31.0 \\
\hline SIDS & $S d$ & 14.4 & 11.6 & 10.6 & 15.4 & 14.2 & 12.4 & 11.0 & 10.9 & 11.0 & 9.0 \\
\hline SIDS & Median & 52.0 & 47.9 & 49.4 & 53.0 & 50.0 & 47.5 & 48.0 & 49.2 & 49.6 & 53.0 \\
\hline Non-SIDS & Moy & 59.1 & 55.5 & 54.9 & 59.8 & 58.0 & 55.8 & 55.5 & 55.1 & 54.8 & 54.5 \\
\hline Non-SIDS & $\mathrm{Nbo}$ & 91.0 & 91.0 & 91.0 & 91.0 & 91.0 & 91.0 & 91.0 & 91.0 & 91.0 & 91.0 \\
\hline Non-SIDS & $S d$ & 21.4 & 21.5 & 21.1 & 21.2 & 21.8 & 21.8 & 21.2 & 21.1 & 21.1 & 21.2 \\
\hline Non-SIDS & Median & 59.1 & 52.9 & 50.7 & 60.1 & 57.7 & 53.8 & 52.0 & 51.0 & 51.3 & 51.8 \\
\hline LDCs non-SIDS & Moy & 66.5 & 63.2 & 62.4 & 67.1 & 65.8 & 63.6 & 62.8 & 62.7 & 62.3 & 61.0 \\
\hline LDCs non-SIDS & Nbo & 38.0 & 38.0 & 38.0 & 38.0 & 38.0 & 38.0 & 38.0 & 38.0 & 38.0 & 38.0 \\
\hline LDCs non-SIDS & $S d$ & 15.8 & 16.6 & 15.9 & 15.6 & 16.3 & 16.7 & 16.5 & 16.1 & 15.7 & 15.9 \\
\hline LDCs non-SIDS & Median & 62.5 & 58.0 & 58.8 & 63.5 & 61.2 & 59.0 & 58.0 & 58.7 & 59.1 & 59.2 \\
\hline LDCs/non-LDCs & $\begin{array}{l}\text { Wilcoxonn-z } \\
\text { pvalue-z }\end{array}$ & $\begin{array}{l}-3.4 \\
0.001\end{array}$ & $\begin{array}{l}-3.6 \\
0.000\end{array}$ & $\begin{array}{l}-3.7 \\
0.000\end{array}$ & $\begin{array}{l}-3.5 \\
0.000\end{array}$ & $\begin{array}{l}-3.5 \\
0.000\end{array}$ & $\begin{array}{l}-3.7 \\
0.000\end{array}$ & $\begin{array}{l}-3.5 \\
0.001\end{array}$ & $\begin{array}{l}-3.7 \\
0.000\end{array}$ & $\begin{array}{l}-3.7 \\
0.000\end{array}$ & $\begin{array}{l}-2.5 \\
0.012\end{array}$ \\
\hline SIDS/non-SIDS & Wilcoxonn-z & 1.0 & 1.3 & 0.9 & 0.9 & 1.2 & 1.3 & 1.2 & 1.1 & 0.8 & -0.6 \\
\hline & pvalue-z & 0.294 & 0.203 & 0.360 & 0.382 & 0.225 & 0.191 & 0.218 & 0.275 & 0.446 & 0.551 \\
\hline SIDS/LDCs non-SIDS & Wilcoxonn-z & 2.6 & 2.9 & 2.8 & 2.4 & 2.8 & 3.0 & 2.8 & 3.0 & 2.6 & 0.7 \\
\hline & pvalue-z & 0.010 & 0.004 & 0.006 & 0.016 & 0.005 & 0.003 & 0.006 & 0.003 & 0.009 & 0.454 \\
\hline
\end{tabular}

Source: CERDI (2006). 
Appendix Table A9

Share of agriculture etc in GDP

By groups of countries, by decades, 5-year periods and Wilcoxon tests

\begin{tabular}{|c|c|c|c|c|c|c|c|c|c|c|c|}
\hline Groups & Statistics & $1970-79$ & $1980-89$ & $1990-99$ & $1970-74$ & $1975-79$ & $1980-84$ & $1985-89$ & $1990-94$ & 1995-99 & $2000-04$ \\
\hline Developing countries & Moy & 45.0 & 40.7 & 38.2 & 46.0 & 44.0 & 41.2 & 40.1 & 38.5 & 37.4 & 34.5 \\
\hline Developing countries & Nbo & 122.0 & 122.0 & 122.0 & 122.0 & 122.0 & 122.0 & 122.0 & 122.0 & 122.0 & 122.0 \\
\hline Developing countries & $S d$ & 26.1 & 25.2 & 24.9 & 26.2 & 26.2 & 26.4 & 24.5 & 24.3 & 25.7 & 25.4 \\
\hline Developing countries & Median & 42.7 & 35.7 & 32.3 & 42.8 & 42.4 & 36.9 & 34.3 & 32.6 & 30.9 & 26.3 \\
\hline Least developed countries & Moy & 63.2 & 59.8 & 57.5 & 63.4 & 62.9 & 61.1 & 58.6 & 57.0 & 57.3 & 54.2 \\
\hline Least developed countries & Nbo & 50.0 & 50.0 & 50.0 & 50.0 & 50.0 & 50.0 & 50.0 & 50.0 & 50.0 & 50.0 \\
\hline Least developed countries & $S d$ & 25.1 & 23.6 & 23.9 & 26.1 & 24.4 & 24.7 & 23.1 & 23.2 & 25.1 & 25.5 \\
\hline Least developed countries & Median & 65.0 & 59.2 & 58.6 & 65.6 & 63.3 & 62.8 & 56.3 & 55.8 & 61.0 & 56.8 \\
\hline Non-least developed countries & Moy & 32.4 & 27.4 & 24.9 & 33.8 & 30.9 & 27.5 & 27.3 & 25.7 & 23.5 & 20.8 \\
\hline Non-least developed countries & Nbo & 72.0 & 72.0 & 72.0 & 72.0 & 72.0 & 72.0 & 72.0 & 72.0 & 72.0 & 72.0 \\
\hline Non-least developed countries & $S d$ & 18.1 & 16.2 & 14.9 & 18.4 & 18.2 & 17.1 & 15.7 & 15.1 & 14.8 & 13.5 \\
\hline Non-least developed countries & Median & 30.5 & 24.7 & 23.3 & 32.7 & 26.8 & 23.8 & 25.8 & 24.6 & 21.0 & 15.6 \\
\hline SIDS & Moy & 38.3 & 33.9 & 31.3 & 38.7 & 37.9 & 34.4 & 33.4 & 32.0 & 30.1 & 27.4 \\
\hline SIDS & Nbo & 31.0 & 31.0 & 31.0 & 31.0 & 31.0 & 31.0 & 31.0 & 31.0 & 31.0 & 31.0 \\
\hline SIDS & $S d$ & 22.4 & 20.4 & 21.3 & 23.1 & 22.0 & 21.4 & 19.8 & 20.3 & 22.6 & 23.0 \\
\hline SIDS & Median & 35.7 & 29.0 & 27.8 & 33.0 & 34.6 & 30.3 & 29.0 & 27.5 & 26.6 & 23.0 \\
\hline Non-SIDS & Moy & 47.3 & 43.0 & 40.6 & 48.4 & 46.1 & 43.6 & 42.4 & 40.7 & 39.8 & 36.9 \\
\hline Non-SIDS & Nbo & 91.0 & 91.0 & 91.0 & 91.0 & 91.0 & 91.0 & 91.0 & 91.0 & 91.0 & 91.0 \\
\hline Non-SIDS & $S d$ & 26.9 & 26.4 & 25.7 & 26.9 & 27.3 & 27.5 & 25.6 & 25.2 & 26.4 & 25.8 \\
\hline Non-SIDS & Median & 45.3 & 37.5 & 33.9 & 46.2 & 43.7 & 38.8 & 38.3 & 35.5 & 32.4 & 29.8 \\
\hline LDCs non-SIDS & Moy & 66.2 & 63.4 & 61.0 & 66.3 & 66.1 & 64.7 & 62.0 & 60.4 & 60.9 & 57.8 \\
\hline LDCs non-SIDS & $\mathrm{Nbo}$ & 38.0 & 38.0 & 38.0 & 38.0 & 38.0 & 38.0 & 38.0 & 38.0 & 38.0 & 38.0 \\
\hline LDCs non-SIDS & $S d$ & 25.1 & 23.9 & 24.3 & 26.1 & 24.5 & 24.8 & 23.6 & 23.8 & 25.1 & 24.7 \\
\hline LDCs non-SIDS & Median & 69.1 & 63.2 & 62.9 & 68.5 & 65.5 & 67.5 & 63.1 & 61.5 & 61.9 & 59.0 \\
\hline LDCs/non-LDCs & $\begin{array}{l}\text { Wilcoxonn-z } \\
\text { pvalue-z }\end{array}$ & $\begin{array}{l}-6.2 \\
0.000\end{array}$ & $\begin{array}{l}-6.9 \\
0.000\end{array}$ & $\begin{array}{l}-7.0 \\
0.000\end{array}$ & $\begin{array}{l}-5.9 \\
0.000\end{array}$ & $\begin{array}{l}-6.5 \\
0.000\end{array}$ & $\begin{array}{l}-6.8 \\
0.000\end{array}$ & $\begin{array}{l}-6.9 \\
0.000\end{array}$ & $\begin{array}{l}-6.9 \\
0.000\end{array}$ & $\begin{array}{l}-6.9 \\
0.000\end{array}$ & $\begin{array}{l}-7.0 \\
0.000\end{array}$ \\
\hline SIDS/non-SIDS & Wilcoxonn-z & 1.6 & 1.6 & 1.7 & 1.8 & 1.4 & 1.5 & 1.5 & 1.7 & 1.9 & 2.0 \\
\hline & pvalue-z & 0.116 & 0.109 & 0.083 & 0.077 & 0.175 & 0.138 & 0.130 & 0.098 & 0.062 & 0.051 \\
\hline SIDS/LDCs non-SIDS & Wilcoxonn-z & 4.2 & 4.7 & 4.5 & 4.1 & 4.4 & 4.5 & 4.5 & 4.6 & 4.5 & 4.6 \\
\hline & pvalue-z & 0.000 & 0.000 & 0.000 & 0.000 & 0.000 & 0.000 & 0.000 & 0.000 & 0.000 & 0.000 \\
\hline
\end{tabular}

Source: CERDI (2006). 
Appendix Table A10

Export concentration

By groups of countries, by decades, 5-year periods and Wilcoxon tests

\begin{tabular}{|c|c|c|c|c|c|c|c|c|c|c|c|}
\hline Groups & Statistics & $1970-79$ & $1980-89$ & $1990-99$ & $1970-74$ & $1975-79$ & $1980-84$ & $1985-89$ & $1990-94$ & 1995-99 & $2000-04$ \\
\hline Developing countries & Moy & 47.5 & 38.2 & 39.4 & 49.5 & 45.3 & 37.0 & 39.4 & 40.2 & 38.6 & 39.4 \\
\hline Developing countries & Nbo & 122.0 & 122.0 & 122.0 & 122.0 & 122.0 & 122.0 & 122.0 & 122.0 & 122.0 & 122.0 \\
\hline Developing countries & $S d$ & 22.1 & 19.1 & 24.0 & 23.4 & 22.4 & 19.8 & 20.5 & 24.2 & 24.6 & 26.3 \\
\hline Developing countries & Median & 47.4 & 37.7 & 35.2 & 49.8 & 43.0 & 36.3 & 38.6 & 35.9 & 35.4 & 34.4 \\
\hline Least developed countries & Moy & 50.7 & 45.0 & 48.5 & 52.2 & 49.2 & 43.4 & 46.5 & 49.2 & 47.8 & 49.9 \\
\hline Least developed countries & $\mathrm{Nbo}$ & 50.0 & 50.0 & 50.0 & 50.0 & 50.0 & 50.0 & 50.0 & 50.0 & 50.0 & 50.0 \\
\hline Least developed countries & $S d$ & 17.3 & 17.0 & 19.1 & 19.2 & 17.5 & 17.9 & 18.1 & 19.1 & 20.8 & 23.0 \\
\hline Least developed countries & Median & 48.3 & 43.6 & 47.0 & 50.3 & 46.0 & 43.8 & 42.6 & 48.6 & 48.4 & 46.1 \\
\hline Non-least developed countries & Moy & 45.3 & 33.5 & 33.1 & 47.7 & 42.7 & 32.5 & 34.5 & 34.0 & 32.3 & 32.1 \\
\hline Non-least developed countries & Nbo & 72.0 & 72.0 & 72.0 & 72.0 & 72.0 & 72.0 & 72.0 & 72.0 & 72.0 & 72.0 \\
\hline Non-least developed countries & $S d$ & 24.8 & 19.1 & 25.1 & 26.0 & 25.0 & 19.8 & 20.7 & 25.5 & 25.2 & 26.1 \\
\hline Non-least developed countries & Median & 45.7 & 35.0 & 26.3 & 48.4 & 39.7 & 30.9 & 32.2 & 27.8 & 26.7 & 26.5 \\
\hline SIDS & Moy & 56.3 & 42.6 & 42.9 & 59.6 & 53.1 & 42.3 & 42.9 & 42.1 & 43.6 & 45.9 \\
\hline SIDS & Nbo & 31.0 & 31.0 & 31.0 & 31.0 & 31.0 & 31.0 & 31.0 & 31.0 & 31.0 & 31.0 \\
\hline SIDS & $S d$ & 14.8 & 16.3 & 15.1 & 15.2 & 16.2 & 18.4 & 16.3 & 16.2 & 15.9 & 20.8 \\
\hline SIDS & Median & 55.6 & 43.8 & 43.1 & 58.2 & 52.9 & 39.2 & 41.6 & 42.8 & 40.0 & 42.6 \\
\hline Non-SIDS & Moy & 44.5 & 36.7 & 38.2 & 46.1 & 42.7 & 35.2 & 38.3 & 39.5 & 36.9 & 37.2 \\
\hline Non-SIDS & Nbo & 91.0 & 91.0 & 91.0 & 91.0 & 91.0 & 91.0 & 91.0 & 91.0 & 91.0 & 91.0 \\
\hline Non-SIDS & $S d$ & 23.5 & 19.8 & 26.3 & 24.8 & 23.6 & 20.0 & 21.7 & 26.4 & 26.8 & 27.7 \\
\hline Non-SIDS & Median & 43.2 & 36.9 & 31.1 & 43.2 & 38.7 & 33.5 & 35.4 & 35.4 & 29.8 & 29.9 \\
\hline LDCs non-SIDS & Moy & 50.2 & 44.1 & 48.4 & 51.6 & 48.8 & 41.8 & 46.5 & 50.1 & 46.6 & 46.8 \\
\hline LDCs non-SIDS & Nbo & 38.0 & 38.0 & 38.0 & 38.0 & 38.0 & 38.0 & 38.0 & 38.0 & 38.0 & 38.0 \\
\hline LDCs non-SIDS & $S d$ & 17.5 & 16.3 & 20.4 & 20.0 & 16.9 & 16.6 & 18.0 & 20.0 & 22.3 & 22.8 \\
\hline LDCs non-SIDS & Median & 47.3 & 43.6 & 47.0 & 50.3 & 45.0 & 43.8 & 42.6 & 49.3 & 47.1 & 45.6 \\
\hline LDCs/non-LDCs & $\begin{array}{l}\text { Wilcoxonn-z } \\
\text { pvalue-z }\end{array}$ & $\begin{array}{l}-1.3 \\
0.183\end{array}$ & $\begin{array}{l}-3.2 \\
0.001\end{array}$ & $\begin{array}{l}-4.0 \\
0.000\end{array}$ & $\begin{array}{l}-1.1 \\
0.254\end{array}$ & $\begin{array}{l}-1.8 \\
0.079\end{array}$ & $\begin{array}{l}-3.1 \\
0.002\end{array}$ & $\begin{array}{l}-3.2 \\
0.001\end{array}$ & $\begin{array}{l}-4.0 \\
0.000\end{array}$ & $\begin{array}{l}-3.8 \\
0.000\end{array}$ & $\begin{array}{l}-4.1 \\
0.000\end{array}$ \\
\hline SIDS/non-SIDS & $\begin{array}{l}\text { Wilcoxonn-z } \\
\text { pvalue-z }\end{array}$ & $\begin{array}{l}-2.8 \\
0.004\end{array}$ & $\begin{array}{l}-1.7 \\
0.094\end{array}$ & $\begin{array}{l}-1.5 \\
0.131\end{array}$ & $\begin{array}{l}-3.2 \\
0.002\end{array}$ & $\begin{array}{l}-2.4 \\
0.015\end{array}$ & $\begin{array}{l}-1.7 \\
0.087\end{array}$ & $\begin{array}{l}-1.4 \\
0.156\end{array}$ & $\begin{array}{l}-1.1 \\
0.286\end{array}$ & $\begin{array}{l}-2.0 \\
0.044\end{array}$ & $\begin{array}{l}-2.1 \\
0.034\end{array}$ \\
\hline SIDS/LDCs non-SIDS & Wilcoxonn-z & -1.6 & 0.2 & 1.1 & -1.7 & -1.0 & 0.0 & 0.5 & 1.7 & 0.3 & 0.0 \\
\hline & pvalue-z & 0.114 & 0.819 & 0.252 & 0.080 & 0.341 & 1.000 & 0.625 & 0.098 & 0.800 & 0.981 \\
\hline
\end{tabular}

Source: CERDI (2006). 